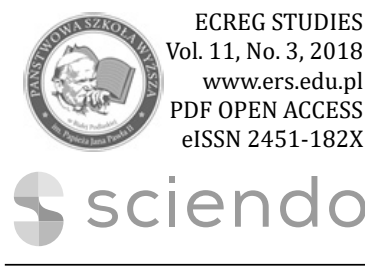

Authors' contribution/ Wkład autorów:

A. Zaplanowanie badań/

Study design

B. Zebranie danych/

Data collection

C. Analiza statystyczna/

Statistical analysis

D. Interpretacja danych/

Data interpretation

E. Przygotowanie tekstu/

Manuscript preparation

F. Opracowanie

piśmiennictwa/

Literature search

G. Pozyskanie funduszy/

Funds collection

\section{ECONOMIC AND REGIONAL STUDIES}

STUDIA EKONOMICZNE I REGIONALNE

ISSN 2083-3725

Volume 11, No. 3, 2018

\title{
NON-ECONOMIC FACTORS AFFECTING EMPLOYMENT IN NON-GOVERNMENTAL ORGANIZATIONS
}

\section{POZAEKONOMICZNE CZYNNIKI WPEYWAJĄCE NA PODEJMOWANIE PRACY W ORGANIZACJACH POZARZĄDOWYCH}

\author{
Piotr Frączek $^{(\mathrm{A}, \mathrm{C}, \mathrm{D}, \mathrm{E}, \mathrm{F}, \mathrm{G})}$, Patrycja Pater ${ }^{(\mathrm{B}, \mathrm{C}, \mathrm{D}, \mathrm{E}, \mathrm{G})}$
}

${ }^{1}$ The Jan Grodek State Vocational Academy in Sanok/

Państwowa Wyższa Szkoła Zawodowa im. J. Grodka w Sanoku

Frączek, P., Pater, P. (2018). Non-economic factors affecting employment in non-governmental organizations/ Pozaekonomiczne czynniki wpływające na podejmowanie pracy $\mathrm{w}$ organizacjach pozarządowych. Economic and Regional Studies, 11(30), 129-147.

https://doi.org/10.2478/ers-2018-0030

\section{ORIGINAL ARTICLE}

JEL code: I39, D64, L31

Submitted:

December 2017

Accepted:

July 2018

Tables: 14

Figures: 1

References: 38

\section{Summary}

Subject and purpose of work: The aim of the paper is to identify non-economic factors influencing employment in non-governmental organizations in the Subcarpathian Province.

Materials and methods: Surveys were conducted in a group of 30 people managing non-governmental organizations.

Results: In the Subcarpathian Province, the factors not connected to economy that encourage involvement in the work of non-governmental organisations include education, marital status, labour market activity, gender, religiousness, and moral authority associated with charitable activities. The factors such as age, personal experience of difficult life situations, or observing charity activities done by family members and friends have an insignificant effect on the involvement in the work of nongovernmental entities.

Conclusions: The activities of state institutions of social policy whose goal is to increase the participation of citizens in the third sector entities should aim to give them an opportunity of obtaining the highest level of education possible, stable employment in the labour market, as well as creating conditions for families to function properly. Moreover, public institutions should conduct social campaigns to show citizens that working in the third sector enriches their social and personal life.

Keywords: non-governmental sector, employment in non-governmental organizations, non-economic determinants, the Subcarpathian Province

ORYGINALNY ARTYKUE NAUKOWY

Klasyfikacja JEL: I39, D64, L31

\section{Zgłoszony:}

Grudzień 2017

Zaakceptowany: Lipiec 2018

Tabele: 14

Rysunki: 1

Literatura: 38

\section{Streszczenie}

Przedmiot i cel pracy: Celem pracy jest wskazanie czynników pozaekonomicznych wpływających na podejmowanie pracy w organizacjach pozarządowych w województwie podkarpackim.

Materiały i metody: Badania ankietowe przeprowadzono w grupie 30 osób kierujących organizacjami pozarządowymi.

Wyniki: W województwie podkarpackim do pozaekonomicznych czynników skłaniających do angażowania się w pracę organizacji pozarządowych można zaliczyć wykształcenie, stan cywilny, aktywność na rynku pracy, płeć, religijność i posiadanie autorytetów moralnych związanych z działalnościa dobroczynną. Mało istotne okazały się natomiast takie czynniki jak wiek, osobiste doświadczanie trudnych sytuacji życiowych czy też obserwowanie działań dobroczynnych wśród rodziny i przyjaciół. Wnioski: Działania państwowych instytucji polityki społecznej ukierunkowana na zwiększanie zaangażowania obywateli $\mathrm{w}$ działalność podmiotów $\mathrm{z}$ trzeciego sektora powinny zmierzać do stworzenia możliwości uzyskania jak najwyższego poziomu wykształcenia, stabilnego zatrudnienia na rynku pracy, a także stworzenia możliwości prawidłowego funkcjonowania rodziny. Ponadto instytucje publiczne powinny prowadzić kampanie społeczne, aby wskazywać, że praca na rzecz trzeciego sektora wzbogaca życie społeczne i osobiste.

Słowa kluczowe: sektor pozarządowy, podejmowanie pracy w organizacjach pozarządowych, determinanty pozaekonomiczne, województwo podkarpackie

Address for correspondence/ Adres korespondencyjny: $d r$ Piotr Fraczek (ORCID 0000-0001-8332-5801), mgr Patrycja Pater (ORCID 0000-00021326-4916), Państwowa Wyższa Szkoła Zawodowa im. J. Grodka w Sanoku, ul. Mickiewicza 21, 38-500 Sanok, Polska, tel. +48 664-766-694, e-mail: piotrfraczek1@gmail.com; e-mail: pater.snk@gmail.com

Journal indexed in/ Czasopismo indeksowane w: AgEcon Search, AGRO, BazEkon, Index Copernicus Journal Master List, ICV 2017: 100,00; Polish Ministry of Science and Higher Education 2016: 9 points/ AgEcon Search, AGRO, BazEkon, Index Copernicus Journal Master List ICV 2017: 100,00; Ministerstwie Nauki i Szkolnictwa Wyższego 2016: 9 punktów. Copyright: @ 2018 Pope John Paul II State School of Higher Education in Biała Podlaska, Piotr Frączek, Patrycja Pater. All articles are distributed under the terms of the Creative Commons Attribution-NonCommercial-ShareAlike 4.0 International (CC BY-NC-SA 4.0) License (http://creativecommons.org/licenses/by-nc-sa/4.0/) allowing third parties to copy and redistribute the material in any medium or format and to remix, transform, and build upon the material, provided the original work is properly cited and states its license. 


\section{Introduction}

The social policy of each country has a multiterritorial character, as it refers to many areas of social life. What is more, the state, self-governments and non-governmental organizations which aim at shaping the suitable well-being of the people, prodevelopment social structures and social relations are forced to take actions in different fields, such as: demographic, family and educational policy, health care, social security policy and social assistance. Meeting social needs as well as the methods of providing assistance for citizens are affected by numerous factors, mainly the political and formal concept of the state.

Before 1989 in Poland, the country was significantly involved in satisfying the needs of its citizens due to the prevailing system. However, it has often denied the existence of such problems as poverty, unemployment or social exclusion. Socialism itself was considered a solution to social problems, such as improving people's living conditions. At that time, there were also non-governmental organizations which supported people in need, however, they were of negligible importance from the perspective of social policy. After the transformation of the political system in 1989, the idea of civil society was reborn in Poland. This is a broad concept that includes various features. Its essence lies in the fact that the society possess the rights to organize and coordinate their actions by establishing institutions without the state supervision. These organizations are to satisfy the needs which cannot be fulfilled neither by the state nor by the market (Kietlińska, 2010). Due to their location between the public and private sectors, these organizations are referred to as non-governmental organizations, non-profit organizations (NGOs), social economy entities or third sector organizations. Their role in the process of meeting the people's needs is becoming more significant in the civic state. This is undoubtedly connected to the inefficiencies of the state entities of social policy caused by the following factors: the lack of adequate financial resources, insufficient social infrastructure or incomplete identification of social needs. The issue of the increasing importance of NGOs has been raised by many authors (see, among others, Grotkowski, 2011; Zielińska, 2011; Kietlińska, 2010; Wang, Graddy, 2008; Tyrakowski, 2007; Grewiński, Kamiński, 2007; Van Willigen, 2000). Moreover, many studies have been conducted in order to investigate the factors determining the undertaking of the charity work (see, among others, Bochyńska-Smigielska, 2012; Taniguchi, 2012; Lee, Chang, 2007; Sliwak, 2000). The review of these studies reveals that certain socio-demographic and economic factors can encourage people to undertake charity work and become involved in the activities of non-governmental entities. This article explores the aforementioned issues. Its aim is to attempt to present the influence of non-economic factors on taking up work in non-governmental organizations. Defining people's motives of charity activities of

\section{Wstęp}

Polityka społeczna każdego państwa ma charakter wieloobszarowy. Oznacza to, że odnosi się ona do wielu obszarów życia społecznego, a państwo, samorządy i organizacje pozarządowe zmierzając do kształtowania odpowiedniego bytu ludności, prorozwojowych struktur społecznych oraz stosunków społecznych, zmuszone są podejmować działania m.in. w zakresie polityki demograficznej, rodzinnej, edukacyjnej, ochrony zdrowia, polityki zabezpieczenia społecznego i pomocy społecznej. Zaspokajanie potrzeb społecznych oraz sposoby udzielania pomocy uwarunkowane są wieloma czynnikami, w tym głównie koncepcją ustrojową i formalną państwa.

W Polsce przed 1989 r., ze względu na panujący ustrój, państwo wkraczało w istotny sposób w zaspokajanie potrzeb obywateli, często jednak negując występowanie problemów społecznych takich jak np. ubóstwo, bezrobocie czy wykluczenie społeczne. Sam ustrój socjalistyczny uważany był bowiem za gwarancję rozwiązywania problemów społecznych i zabezpieczania odpowiednich warunków bytowych obywateli. Istniały oczywiście w tym czasie także pozarządowe formy pomocy na przykład dla osób ubogich, jednak miały one z punktu widzenia polityki społecznej marginalne znaczenie. Po zmianie ustroju w 1989 r. w Polsce odrodziła się idea społeczeństwa obywatelskiego. Termin ten jest pojęciem szerokim, któremu przypisuje się szereg cech. Jego istota polega na tym, że społeczeństwo uzyskuje określone prawa, dzięki którym może organizować i koordynować swoje działania poprzez powoływanie określonych instytucji, wolnych od państwowego nadzoru. Organizacje te mają za zadanie zaspokajać takie potrzeby, których nie jest w stanie zapewnić ani państwo, ani rynek (Kietlińska, 2010). Ze względu na swoje umiejscowienie pomiędzy sektorem publicznym i prywatnym, organizacje te nazywane są organizacjami pozarządowymi, organizacjami non-profit (NGO), podmiotami gospodarki społecznej bądź organizacjami trzeciego sektora. Ich rola $\mathrm{w}$ procesie zaspokajania potrzeb społecznych w państwie obywatelskim ciągle rośnie. Związane jest to niewątpliwie z faktem niewydolności państwowych podmiotów polityki społecznej spowodowanym np. brakiem odpowiednich środków finansowych, niewystarczającej infrastruktury społecznej czy też niepełnego rozpoznania potrzeb społecznych. Wzrost znaczenia podmiotów NGOs podnosiło w swoich pracach wielu autorów (zob. m.in. Grotkowski, 2011; Zielińska, 2011; Kietlińska, 2010; Wang, Graddy, 2008; Tyrakowski, 2007; Grewiński, Kamiński, 2007; Van Willigen, 2000). Powstało również wiele opracowań, w których autorzy podejmowali próbę wskazania czynników determinujących podejmowanie działalności dobroczynnej (zob. m.in. Bochyńska-Śmigielska, 2012; Taniguchi, 2012; Lee, Chang, 2007; Śliwak, 2000). Przegląd tych badań pozwala wnioskować, że wybrane czynniki społeczno-demograficzne i ekonomiczne mogą powodować, że osoby będą podejmowały działalność dobroczynną i angażowały się $\mathrm{w}$ działalność podmiotów pozarządowych. Tym właśnie problemom poświęcony jest prezentowany artykuł, którego celem jest podjęcie 
people involved in the work for the non-government sector and the implementation of the research in this area proves that the article is innovative and of the interdisciplinary nature.

\section{Determinants of undertaking charity work in the subject literature}

In the subject literature, many authors have repeatedly attempted to identify factors which encourage people to undertake charity work or to provide financial support for non-governmental organizations (see, for example, Lee, Chang, 2007; Wang, Graddy, 2008; Śliwak, 2000; Kitchen, Dalton, 1990; Yi, 2010). The review of these studies enables the identification of certain socio-demographic and economic factors which determine the altruistic behavior. Yet, a significant part of empirical research and theoretical analysis has been conducted outside Poland.

The definitions of charity, philanthropy, volunteering and altruism should be set out at the beginning of the considerations. The concept of charity is closely connected to the idea of loving your own neighbour functioning in Christianity. In this sense, it derives from the idea of loving your own neighbour depicted by the parable of the Good Samaritan. Also in Judaism and Islam this kind of love is believed to be a religious order to help the poorest. Therefore, it refers to taking direct aid measures to help the poor, sick and disabled. Philanthropy is also associated with love for others, fraternal love and compassion. However, this concept derives from ancient Greece and Rome, thus it is connected to the secular ideas of humanitarianism. In this context, a philanthropist strives to improve the fate of the entire communities by creating social order, introducing necessary reforms, funding activities which are targeted at helping those in need (for instance, providing financial support) and developing scientific or cultural activities. Voluntary work is an activity done for the whole natural environment. Therefore, it is a broader concept than charity and philanthropy, covering both human and environmental protection and animal aid (Górecki, 2013, p. 82). Many definitions of altruism can be found in the subject literature. Some scholars claim that it is a part of a wider category of pro-social behavior (Bar-Tal, 1976, Reykowski, 1979, Kenrick, Neuberg and Cialdini, 2002), while others point out that both concepts are understood as similar or identical (Karyłowki, 1982a; Jarymowicz, 1979). All approaches pay attention to such features of altruism as: conscious and voluntary undertaking of action aimed at benefiting another person without expecting a prize, because it is an end in itself (Śliwak, 2005).

The next step of considerations is the search for factors that determine the undertaking of charitable activities. The literature contains several models explaining the activities of volunteers, which focus próby przedstawienia wpływu czynników pozaekonomicznych na podejmowanie pracy w organizacjach pozarządowych. Określenie motywów działań dobroczynnych osób zaangażowanych w pracę na rzecz sektora pozarządowego i realizacja $\mathrm{w}$ tym zakresie badania sprawia, że artykuł zawiera element nowatorski i posiada interdyscyplinarny charakter.

\section{Determinanty podejmowania działalności dobro- czynnej w literaturze przedmiotu}

W literaturze przedmiotu podejmowano wielokrotnie próbe zidentyfikowania czynników, które wpływają na to, że ludzie podejmują działalność dobroczynną, bądź też wspierają finansowo organizacje z sektora pozarządowego (zob. np. Lee, Chang, 2007; Wang, Graddy, 2008; Śliwak, 2000; Kitchen, Dalton, 1990; Yi, 2010). Przegląd tych badań pozwala określić pewne czynniki społeczno-demograficzne i ekonomiczne, które determinują zachowania altruistyczne. Znaczna część badań empirycznych i analiz teoretycznych prowadzona była jednak poza Polską.

$\mathrm{Na}$ wstępnie rozważań należy ustalić definicje dobroczynności, filantropii, wolontariatu oraz altruizmu. Pojęcie dobroczynności ściśle wiąże się z ideami miłości bliźniego funkcjonującymi w religii chrześcijańskiej. W tym rozumieniu wywodzi się od miłości bliźniego obrazowanej przez przypowieść o miłosiernym Samarytaninie. Także w judaizmie i islamie rozumiana jest jako religijny nakaz pomagania najbiedniejszym. Odnosi się zatem do podejmowania bezpośrednich działań pomocowych potrzebującym, chorym niepełnosprawnym. Filantropia także wiąże się z umiłowaniem człowieka, braterską miłością i współczuciem, jednakże pojęcie to wywodzi się ze starożytnej Grecji i Rzymu, a więc wiąże się ze świeckimi ideami humanitaryzmu. W tym kontekście jest dążeniem do poprawy losu całych społeczności poprzez tworzenie porządku społecznego, wprowadzania odpowiednich reform, finansowaniem działań na rzecz potrzebujących (np. udzielaniem pomocy materialnej) oraz rozwojem działalności naukowej czy kulturalnej. Wolontariat jest działaniem na rzecz całego środowiska naturalnego, a zatem jest pojęciem szerszym od dobroczynności i filantropii obejmującym zarówno działania na rzecz człowieka, jak i ochronę środowiska, w tym pomoc zwierzętom (Górecki, 2013, s. 82). W literaturze przedmiotu można znaleźć wiele definicji altruizmu, który przez niektórych badaczy rozumiany jest jako pojęcie zawierające się $\mathrm{w}$ szerszej kategorii zachowania prospołecznego (Bar-Tal, 1976; Reykowski, 1979; Kenrick, Neuberg i Cialdini, 2002), a przez innych oba pojęcia rozumiane są jako zbliżone, czy też tożsame (Karyłowki, 1982a; Jarymowicz, 1979). We wszystkich podejściach zwraca się uwagę na takie cechy altruizmu jak: świadome i dobrowolne podjęcie działania mającego przynieść korzyść innej osobie bez oczekiwania na nagrode, ponieważ stanowi cel sam w sobie (Śliwak, 2005).

Kolejnym krokiem rozważań jest poszukiwanie czynników warunkujących podejmowanie działań dobroczynnych. W literaturze znajduje się kil- 
on various aspects of human functioning. On the one hand, they focus on collective goods, and on the other, on individual goods as a basis for motivation. The collective goods model seeks determinants in the social demand for charitable activity as well as social pressure. The private goods model assumes that people engage in charitable activities because they expect to receive a certain return for it, e.g. in the form of new skills useful on the labour market (skill development) or due to private motives or pure altruism (Influence and Search) (Govekar, Govekar, 2002). This article focuses on searching for non-economic factors that determine the undertaking of charity activity.

In his work, J. Śliwiak (2000) suggests that charity can be conditioned by, inter alia, an acquaintance with the person who is need of help, observation of altruistic behaviours in everyday life, feeling of happiness and success, as well as living in small communities (e.g. people from large communities, cities help less frequently than people living in small towns or villages).

Partially, these theses are confirmed by foreign research. The analyses conducted by Y. K. Lee and C. T. Chang (2007) ${ }^{1}$ on a group of 730 residents of Taiwan can constitute a good example. These studies have shown that gender, age, family situation, and marital status are the determinants of undertaking charity activities. The analyses conducted by $\mathrm{H}$. Taniguchi (2012) on a group of American people sought the determinants of formal and informal volunteering. Formal activities were associated with a longer time spent on education, religious activity, a longer interaction with a friend, as well as marital status (having a family). Informal volunteering, on the other hand, involved more time spent with family and friends.

The studies carried out in the Lublin Province on a group of 168 adolescents, who were involved in volunteering for a minimum of six months, explored the family conditions as the reasons for undertaking such activities. Conclusions from the analyses show that a democratic atmosphere prevailing in the family home, warm relations between family members, as well as clearly defined rules and norms of conduct foster the undertaking of charity activities. Another important factor is having at least one authority from two identified categories: respected people and people from the volunteers' environment, who are important to them and provide positive patterns of behaviour. These patterns of behaviour most often come from parents, and subsequently from teachers or volunteer carers. At the same time, it should be noted that most of the parents were not involved in charity activity, but they supported such behaviour in their children, showing interest and satisfaction. Researchers suggest the great importance of family environment on the undertaking of charity activities by young people (Braun, 2012).

The subject literature also points to the motivation of volunteers to undertake aid activities, which,

\footnotetext{
${ }^{1}$ Lee and Chang (2007) conducted research on the determinants of charity assuming that the altruistic activities can take only two forms: volunteering or monetary support.
}

ka modeli wyjaśniających działania wolontariuszy, koncentrujących się na różnych aspektach funkcjonowania człowieka. Skupiają się one $\mathrm{z}$ jednej strony na dobrach zbiorowych a drugiej na dobrach indywidualnych jako podstawie motywacji. Model dóbr zbiorowych (The collective goods model) poszukuje determinant $\mathrm{w}$ społecznym popycie na działalnośc charytatywną oraz presji społecznej. Model dóbr prywatnych (The private goods model) zakłada, że osoby podejmują działalność oczekując, że otrzymaja za nią pewien zwrot, np. w postaci nowych umiejętności przydatnych na rynku pracy (Skill development) lub ze względu na prywatne motywy lub czysty altruizm (Influence and Search) (Govekar, Govekar, 2002). W niniejszym artykule uwaga skupiła się na poszukiwaniu pozaekonomicznych czynników warunkujących podejmowanie działalności dobroczynnej.

J. Śliwiak (2000) w swojej pracy wskazuje, że dobroczynność mogą warunkować m.in. znajomość osoby potrzebującej pomocy, obserwowanie zachowań altruistycznych w codziennym życiu, poczucie szczęścia i własnego sukcesu oraz zamieszkiwanie w małych społecznościach (np. osoby z dużych skupisk, miast rzadziej pomagają niż osoby zamieszkujące małe miasta lub wieś).

Częściowo tezy te potwierdzają badania zagraniczne. Dobrym przykładem mogą być analizy prowadzone przez Y. K. Lee and C. T. Chang (2007) ${ }^{1}$ w grupie 730 mieszkańców Taiwanu. Badania te wykazały, że płeć, wiek, sytuacja rodzinna i stan cywilny są determinantami podejmowania działalności dobroczynnej. W analizach przeprowadzonych przez H. Taniguchi (2012) na grupie amerykanów poszukiwano determinant podejmowania formalnego oraz nieformalnego wolontariatu. Formalne działania wiązały się z dłuższym czasem spędzonym na edukacji, aktywnością religijną, dłuższym czasem spędzonym z przyjaciółmi oraz stanem cywilnym (posiadanie rodziny). Natomiast nieformalny wolontariat wiąże się z większą ilością czasu spędzonego z rodziną i przyjaciółmi.

W badaniach przeprowadzonych na terenie województwa lubelskiego, na grupie 168 osób w okresie adolescencji, które przez minimum pół roku były zaangażowane w wolontariat, poszukiwano rodzinnych uwarunkowań podejmowania tego typu działań. Wnioski z analiz wskazują, że demokratyczna atmosfera panująca $\mathrm{w}$ domu rodzinnym, ciepłe relacje pomiędzy członkami rodziny, jasno określone zasady i normy postępowania sprzyjają podejmowaniu działań dobroczynnych. Kolejnym ważnym czynnikiem jest posiadanie przynajmniej jednego autorytetu, przy czym zidentyfikowano ich dwie kategorie: osoby cieszące się powszechnym szacunkiem oraz osoby $z$ otoczenia wolontariuszy, ważne dla nich i przekazujące pozytywne wzorce zachowań. Owe wzory postępowania najczęściej pochodzą od rodziców, w dalszej kolejności od nauczycieli czy opiekunów wolontariatu. Jednocześnie należy zaznaczyć, że rodzice nie byli w większości zaangażowani w działalność do-

\footnotetext{
${ }^{1}$ Lee i Chang (2007) prowadzili badania determinantów dobroczynności przy założeniu, że działania altruistyczne mogą przyjmować tylko dwie formy: wolontariat bądź wsparcie pieniężne.
} 
depending on the authors, are divided in different ways. The first division distinguishes internal and external motivation (e.g. expectations that the activity will be noticed and rewarded). In this case, internal motivation may be specific (the goal is to do good in itself) or non-specific (it is associated with the pleasure derived from the performance of activities). Another division lists the normocentric (endocentric) and autotelic motivation. The first is based on the rules of conduct, which the individual assimilates throughout life, and the latter on the individual's need to selflessly do good to other people. Hence, it should be concluded that the motivation to undertake charity activities may result from environmental reasons or the internal human need (for more information see Kanios, 2008).

A review of the results of empirical research and the subject literature allows to determine the model of charity determinants and their hypothetical impact on the altruistic activities, which are presented in Table 1. broczynną, ale wspierali takie zachowania u swoich dzieci wykazując zainteresowanie oraz zadowolenie. Badacze wysunęli wnioski o dużym znaczeniu środowiska rodzinnego $\mathrm{w}$ podejmowanie działań dobroczynnych przez młodzież (Braun, 2012).

W literaturze przedmiotu zwraca się także uwage na motywację wolontariuszy do podejmowania działań pomocowych, którą w zależności od autorów dzieli się w odmienny sposób. Pierwszym podział wyróżnia motywację wewnętrzną i zewnętrzną (np. oczekiwania, że jej aktywność zostanie dostrzeżona i nagrodzona). W tym przypadku motywacja wewnętrzna może mieć charakter specyficzny (celem jest czynienie dobra samo w sobie) lub niespecyficzny (wiąże się z odczuwaniem przyjemności z realizacji działań). Inny podział wymienia motywację normocentryczną (endocentryczną) oraz autoteliczną. Pierwsza opiera się na zasadach postępowania, które jednostka przyswaja sobie przez życie, a druga na potrzebie jednostki do bezinteresownego czynienia dobra na rzecz innych osób. Stąd wnioskować należy, że motywacja do podjęcia działalności dobroczynnej wynikać może z przyczyn zawartych w środowisku lub w wewnętrznej potrzebie człowieka (szerzej zob. Kanios, 2008).

Przegląd wyników badań empirycznych i literatury przedmiotu pozwala na określenie modelu determinant dobroczynności i ich hipotetycznego wpływu na działalność altruistyczną, które prezentuje w tabela 1.

Table 1. Determinants of undertaking charity activities

Tabela 1. Determinanty podejmowania działalności dobroczynnej

\begin{tabular}{|c|c|c|}
\hline \multicolumn{2}{|c|}{$\begin{array}{c}\text { Factors influencing the undertaking of } \\
\text { charity activities/ } \\
\text { Czynniki wpływające na podejmowanie } \\
\text { dobroczynności }\end{array}$} & $\begin{array}{l}\text { Impact of factors on undertaking charity activities/ } \\
\text { Wpływ czynników na podejmowanie działalności dobroczynnej }\end{array}$ \\
\hline \multirow{6}{*}{$\begin{array}{l}\text { Social capital/ } \\
\text { Kapitał spo- } \\
\text { łeczny }\end{array}$} & $\begin{array}{l}\text { Social networks/ } \\
\text { Sieci społeczne }\end{array}$ & $\begin{array}{l}\text { Possession/participation has a positive effect on charity (family, friends, so- } \\
\text { cial organisations)/ } \\
\text { Posiadanie/uczestnictwo ma pozytywny wpływ na dobroczynność (rodzina, } \\
\text { przyjaciele, organizacje społeczne) }\end{array}$ \\
\hline & \begin{tabular}{|l|} 
Informal social networks/ \\
Nieformalne sieci społeczne
\end{tabular} & $\begin{array}{l}\text { Interactions may encourage philanthropy (among family, friends)/ } \\
\text { Interakcje mogą zachęcać do filantropii (wśród rodziny, przyjaciół) }\end{array}$ \\
\hline & $\begin{array}{l}\text { Civic involvement/ } \\
\text { Zaangażowanie obywatel- } \\
\text { skie }\end{array}$ & $\begin{array}{l}\text { Civic involvement, belonging to groups, and a sense of connection with other } \\
\text { members of one’s own group encourages altruism/ } \\
\text { Zaangażowanie obywatelskie, przynależność do grup, poczucie połączenia } \\
\text { z innymi członkami swojej grupy zachęca do altruizmu }\end{array}$ \\
\hline & $\begin{array}{l}\text { Social trust/ } \\
\text { Zaufanie społeczne }\end{array}$ & $\begin{array}{l}\text { "Giving/helping is a matter of trust,” social trust increases the level of cha- } \\
\text { rity/ } \\
\text { „Dawanie/pomaganie jest kwestią zaufania”, zaufanie społeczne zwiększa } \\
\text { poziom dobroczynności }\end{array}$ \\
\hline & $\begin{array}{l}\text { Reporting/offering servi- } \\
\text { ces/ } \\
\text { Zgłaszanie się/ofiarowywa- } \\
\text { nie usług }\end{array}$ & $\begin{array}{l}\text { Volunteering and offering help encourages charity; Volunteers are more often } \\
\text { involved in charity activities; Volunteering raises awareness of social needs/ } \\
\text { Wolontariat, ofiarowywanie swojej pomocy sprzyja działalności dobroczyn- } \\
\text { nej; Wolontariusze częściej angażują się w działalność dobroczynną; Wolon- } \\
\text { tariat rozbudza świadomość potrzeb społecznych }\end{array}$ \\
\hline & $\begin{array}{l}\text { Happiness/ } \\
\text { Szczęście }\end{array}$ & $\begin{array}{l}\text { Optimistic and happy people are more likely to engage in charity activities/ } \\
\text { Osoby optymistyczne, szczęśliwe częściej angażują się w działalność dobro- } \\
\text { czynną }\end{array}$ \\
\hline \multicolumn{2}{|r|}{$\begin{array}{l}\text { Religiousness/ } \\
\text { Religijność }\end{array}$} & $\begin{array}{l}\text { Religious people show greater interest in the needs of others and more often } \\
\text { engage in charity activities/ } \\
\text { Osoby religijne wykazują większe zainteresowanie potrzebami innych, czę- } \\
\text { ściej angażują się w działania dobroczynne }\end{array}$ \\
\hline
\end{tabular}




\begin{tabular}{|c|c|c|}
\hline \multicolumn{2}{|c|}{$\begin{array}{l}\text { Factors influencing the undertaking of } \\
\text { charity activities/ } \\
\text { Czynniki wpływające na podejmowanie } \\
\text { dobroczynności }\end{array}$} & \multirow{2}{*}{$\begin{array}{l}\text { Impact of factors on undertaking charity activities/ } \\
\text { Wpływ czynników na podejmowanie działalności dobroczynnej } \\
\text { A higher level of education increases the willingness to engage in charity ac- } \\
\text { tivities/ } \\
\text { Wyższy poziom osiągniętej edukacji powoduje wzrost chęci do działalności } \\
\text { dobroczynnej }\end{array}$} \\
\hline \multirow{3}{*}{$\begin{array}{c}\text { Human and } \\
\text { financial capital }\end{array}$} & $\begin{array}{l}\text { Education/ } \\
\text { Edukacja }\end{array}$ & \\
\hline & $\begin{array}{l}\text { Income/ } \\
\text { Dochód }\end{array}$ & \multirow{2}{*}{$\begin{array}{l}\text { Income growth, stable financial situation, and having a home increases the } \\
\text { willingness to undertake charity activities/ } \\
\text { Wzrost dochodu, stabilna sytuacja finansowa, posiadanie własnego domu } \\
\text { zwiększa chęć do podejmowania działalności dobroczynnej }\end{array}$} \\
\hline & $\begin{array}{l}\text { Having a home/ } \\
\text { Posiadanie domu }\end{array}$ & \\
\hline \multirow{6}{*}{$\begin{array}{c}\text { Demography/ } \\
\text { Demografia }\end{array}$} & $\begin{array}{l}\text { Age/ } \\
\text { Wiek }\end{array}$ & $\begin{array}{l}\text { Age has a positive effect on charity, i.e. older people are more likely to help } \\
\text { than the younger ones/ } \\
\text { Wiek wpływa pozytywnie na dobroczynność, osoby starsze chętniej poma- } \\
\text { gają niż osoby młode }\end{array}$ \\
\hline & $\begin{array}{l}\text { Sex/ } \\
\text { Płeć }\end{array}$ & $\begin{array}{l}\text { Women engage in charity activities more often than men/ } \\
\text { Kobiety częściej niż mężczyźni angażują się w działalność dobroczynną }\end{array}$ \\
\hline & $\begin{array}{l}\text { Citizenship/ } \\
\text { Obywatelstwo }\end{array}$ & $\begin{array}{l}\text { Unambiguous citizenship situation has a positive effect on charity; People } \\
\text { with permanent citizenship are more willing to engage in charity activities } \\
\text { than residents and immigrants/ } \\
\text { Posiadanie jednoznacznej sytuacji w zakresie obywatelstwa wpływa pozy- } \\
\text { tywnie na dobroczynności; Osoby ze stałym obywatelstwem chętniej anga- } \\
\text { żują się w działalność dobroczynną niż rezydencji, imigranci }\end{array}$ \\
\hline & $\begin{array}{l}\text { Marital status/ } \\
\text { Stan cywilny }\end{array}$ & $\begin{array}{l}\text { Married people engage in charity activities more often than single people/ } \\
\text { Osoby w pozostające związkach małżeńskich częściej angażują się w działal- } \\
\text { ność dobroczynną niż osoby samotne }\end{array}$ \\
\hline & $\begin{array}{l}\text { Number of children/ } \\
\text { Liczba dzieci }\end{array}$ & $\begin{array}{l}\text { An increase in the number of children decreases the willingness to engage in } \\
\text { charity activities/ } \\
\text { Wzrost liczby posiadanych dzieci zmniejsza chęć angażowania się w działal- } \\
\text { ność dobroczynną }\end{array}$ \\
\hline & $\begin{array}{l}\text { Time of living in a particular } \\
\text { community/ } \\
\text { Czas zamieszkiwania w da- } \\
\text { nej społeczności }\end{array}$ & $\begin{array}{l}\text { A longer period of living in a particular community makes people more } \\
\text { involved in charity activities/ } \\
\text { Dłuższy okres zamieszkiwania w danej społeczności sprawia, że osoby będą } \\
\text { częściej angażowały się w działalność dobroczynną }\end{array}$ \\
\hline
\end{tabular}

Source: Own study based on Wang, Graddy (2008) .

Źródło: Opracowanie własne na podst. Wang, Graddy (2008).

This model shows that religious patterns and authorities, relations in the family home and experiences resulting from upbringing can, indeed, determine the undertaking of charity activities - also in Poland.

\section{Methodological assumptions of the research}

Determining the nation-wide factors affecting the involvement of people in the work for the third sector and their empirical verification is a difficult and complex task. However, the presented article has a much more modest purpose, i.e. to indicate what non-economic factors influenced the undertaking of work in non-governmental organizations ${ }^{2}$ in one region of Poland - the Subcarpathian Province.

The author's questionnaire conducted among leaders managing non-governmental organizations was used as the research tool. The questionnaire contained 27 questions (open and semi-open) and

\footnotetext{
${ }^{2}$ The non-governmental organisation within the meaning of article 3 of the Act of April 24, 2003. On public benefit and volunteer work (Journal of Laws of 2018, item 450, as amended) means an entity dealing with public benefit activities. The public benefit activity is a socially advantageous activity, conducted by a non-governmental organisations in the sphere of public tasks specified in the act.
}

Model ten wskazuje, że religijne wzorce i autorytety, stosunki panujące $\mathrm{w}$ domu rodzinnym oraz doświadczenia wynikające $\mathrm{z}$ wychowania mogą faktycznie determinować podejmowanie działalności dobroczynnej - także na terenie Polski.

\section{Założenia metodologiczne badań}

Określenie ogólnokrajowych czynników wpływających na zaangażowanie się osób w pracę na rzecz trzeciego sektora oraz ich empiryczna weryfikacja jest zadaniem trudnym i złożonym. Prezentowany artykuł ma jednak dużo skromniejszy cel tj. wskazać jakie czynniki pozaekonomiczne wpływały na podejmowanie pracy $\mathrm{w}$ organizacjach pozarządowych ${ }^{2}$ w jednym regionie Polski - województwie podkarpackim.

Jako narzędzie badawcze wykorzystano autorski kwestionariusz ankiety, która została przeprowadzona wśród liderów kierujących organizacjami

\footnotetext{
${ }^{2}$ Organizacja pozarządowa w rozumieniu art. 3 Ustawy z dnia 24 kwietnia 2003 r. o działalności pożytku publicznego i o wolontariacie (Dz. U. z 2018 poz. 450 t.j. z późn zm.) oznacza podmiot zajmujacy się działalnościa pożytku publicznego. Działalnościa pożytku publicznego jest działalność społecznie użyteczna, prowadzona przez organizacje pozarządowe w sferze zadań publicznych określonych w ustawie.
} 
information of the imprint nature. The questions included in the questionnaire referred mainly to non-economic factors, which made the person get involved in work for the non-governmental sector. Moreover, the questions included in the questionnaire concerned the organizational forms of the nongovernmental subject which the respondent was in charge of, the number of members or the forms of action undertaken and problems in organizations.

The database of non-governmental organizations operating in the Subcarpathian Province contained on the NGO.pl website - Portal of Non-Governmental Organizations (bazy.ngo.pl) was the sampling frame. The random selection was made using IBM SPSS. The research covered 67 organizations, which were involved in charity activities or social aid ${ }^{3}$. Finally, the authors of the research managed to receive 30 feedback questionnaires. The collected material was subjected to the quantitative and qualitative analysis. Empirical research was conducted in the period from May to September 2016 in the Subcarpathian Province.

After the analysis of the subject literature the following research question was phrased for the purposes of the research:

1. How do the selected non-economic factors determine the undertaking of charity activities?

Subsequently, the following general hypothesis was put forward:

$\mathrm{H}$ : The selected non-economic factors essentially determine the undertaking of charity activities.

Six detailed research hypotheses were put forward to the general hypothesis:

1. Higher level of education, marriages and professional work are conducive to engaging into work in non-governmental organizations.

2. Women and elderly people engage in helping others more often than men and young people.

3. Religiosity and the possession of moral authorities in one's life associated with charity activities increase interest in the needs of others and the willingness to engage in work for the non-governmental sector.

4. Personal experience of difficult life situations related to, among others, homelessness, poverty, unemployment and addictions, is conducive to getting involved in work in non-governmental organizations.

5. Experiencing help, support, mutual understanding in a family home can encourage involvement in work in non-governmental organizations.

6. Involvement in work in non-governmental organizations brings satisfaction and positively affects personal life.

\footnotetext{
${ }^{3}$ Article 4 of the Act of April 24, 2003. On public benefit and volunteer work (Journal of Laws of 2018, item 450, as amended) defines the sphere of public tasks that are dealt with by nongovernmental organisations, such as tasks in the field of social assistance and charity activities.
}

pozarządowymi. Kwestionariusz ankiety zawierał 27 pytań (otwartych i półotwartych) oraz informacje o charakterze metryczkowym. Pytania zawarte w ankiecie odnosiły się głównie do czynników pozaekonomicznych, które sprawiały, iż dana osoba angażowała się w pracę na rzecz sektora pozarządowego. Ponadto pytania zawarte $\mathrm{w}$ ankiecie dotyczyły form organizacyjnych podmiotu pozarządowego, którym kierował respondent, liczby członków czy też form podejmowanych działań oraz problemów występujących w organizacjach.

Operat losowań stanowiła baza danych organizacji pozarządowych działających na terenie województwa podkarpackiego, zawarta na stronie internetowej NGO.pl - Portal Organizacji Pozarządowych (bazy.ngo.pl). Doboru losowego dokonano przy wykorzystaniu IBM SPSS. Badaniem objęto 67 organizacji, które zajmowały się działalnością charytatywną, bądź pomocą społeczną ${ }^{3}$. Ostatecznie autorom badania udało się pozyskać 30 ankiet zwrotnych. Zebrany materiał poddano analizie ilościowej i jakościowej. Badania empiryczne zostały przeprowadzone w okresie maj-wrzesień 2016 r. na terenie województwa podkarpackiego.

Po analizie literatury przedmiotu dla potrzeb badań sformułowano następujące pytanie badawcze:

1. Jak wybrane czynniki pozaekonomiczne determinuja podejmowanie działań dobroczynnych?

W dalszej kolejności postawiono następującą hipotezę ogólną:

$\mathrm{H}$ : Wybrane czynniki pozaekonomiczne w sposób istoty warunkujq podejmowanie działań dobroczynnych.

Do hipotezy ogólnej postawiono sześć szczegółowych hipotez badawczych:

1. Wyższy poziom wykształcenia, pozostawanie w związkach małżeńskich oraz wykonywanie pracy zawodowej sprzyja angażowaniu się $\mathrm{w}$ pracę $\mathrm{w}$ organizacjach pozarządowych.

2. Kobiety oraz osoby starsze częściej angażują się w pomaganie innym niż mężczyźni i osoby młode.

3. Religijność i posiadanie w życiu autorytetów moralnych związanych $\mathrm{z}$ działalnością charytatywną powodują wzrost zainteresowania potrzebami innych i chęć angażowania się w pracę na rzecz sektora pozarządowego.

4. Osobiste doświadczanie trudnych sytuacji życiowych związanych m.in. z bezdomnością, ubóstwem, bezrobociem, uzależnieniami sprzyja angażowaniu się $\mathrm{w}$ pracę $\mathrm{w}$ organizacjach pozarządowych.

5. Doświadczanie pomocy, wsparcia, wzajemnego zrozumienia $\mathrm{w}$ domu rodzinnym może sprzyjać angażowaniu się $\mathrm{w}$ pracę $\mathrm{w}$ organizacjach pozarządowych.

6. Zaangażowanie $\mathrm{w}$ pracę $\mathrm{w}$ organizacjach pozarządowych przynosi satysfakcję i pozytywnie wpływa na życie osobiste.

\footnotetext{
${ }^{3}$ Art 4 Ustawy z dnia 24 kwietnia 2003 r. o działalności pożytku publicznego i o wolontariacie (Dz. U. z 2018 poz. 450 t.j. z późn $\mathrm{zm}$.) określa sferę zadań publicznych, którymi zajmują się organizacje pozarządowe, są to m.in. zadania z zakresu pomocy społecznej i działalności charytatywnej.
} 


\section{Socio-demographic characteristic of the Charakterystyka społeczno-demograficzna re- respondents spondentów}

The age structure of the respondents who are involved in the activities of non-governmental organizations is presented in Table 2 .

Strukturę wiekową badanych osób zaangażowanych w działalność organizacji pozarządowych przedstawia tabela 2 .

Table 2. The age of respondents who work in non-governmental organizations

Tabela 2. Wiek respondentów podejmujących pracę w organizacjach pozarządowych

\begin{tabular}{|l|c|c|c|c|}
\hline & $\begin{array}{c}\text { Woman/ } \\
\text { Kobieta }\end{array}$ & $\begin{array}{c}\text { Man/ } \\
\text { Mężczyzna }\end{array}$ & $\begin{array}{c}\text { Sum/ } \\
\text { Suma }\end{array}$ & $\begin{array}{c}\text { in \%/ } \\
\text { w \% }\end{array}$ \\
\hline $\begin{array}{l}\text { 20-29 years of age/ } \\
\text { 20-29 lat }\end{array}$ & 2 & 1 & $\mathbf{3}$ & $\mathbf{1 0 . 3}$ \\
\hline $\begin{array}{l}\text { 30-39 years of age/ } \\
\text { 30-39 lat }\end{array}$ & 4 & 3 & $\mathbf{7}$ & $\mathbf{2 0 . 7}$ \\
\hline $\begin{array}{l}\text { 40-49 years of age/ } \\
\text { 40-49 lat }\end{array}$ & 3 & 3 & $\mathbf{6}$ & 27.6 \\
\hline $\begin{array}{l}\text { 50-59 years of age/ } \\
\text { 50-59 lat }\end{array}$ & 5 & 3 & $\mathbf{2}$ & $\mathbf{6 . 9}$ \\
\hline $\begin{array}{l}\text { 60-69 years of age/ } \\
\text { 60-69 lat }\end{array}$ & 1 & 1 & $\mathbf{3}$ & $\mathbf{1 0 . 3}$ \\
\hline $\begin{array}{l}\text { 70 years of age and } \\
\text { older/ } \\
\text { 70 lat i więcej }\end{array}$ & 2 & 1 & $\mathbf{2 9}$ & $\mathbf{1 0 0}$ \\
\hline $\begin{array}{l}\text { Total/ } \\
\text { Razem }\end{array}$ & $\mathbf{1 7}$ & $\mathbf{1 2 *}$ & $\mathbf{1 0 0}$ & \\
\hline \multicolumn{1}{c}{ in $\%$ w } & $\mathbf{5 8 . 6}$ & $\mathbf{4 1 . 4}$ & & \\
\hline
\end{tabular}

* 1 man did not specify his age/ 1 mężczyzna nie określił swojego wieku

Source: own study based on the carried out research.

Źródło: Opracowanie własne na podstawie przeprowadzonych badań.

The work of non-governmental organizations often involved people aged 30-39 (7 people), 40-49 (6 people) and 50-59 (8 people). Extreme age groups the youngest and the oldest were less often involved in activities for the third sector. Moreover, women (17 people, i.e.almost $60 \%$ of the total) more often engaged in the activities of non-governmental organizations than men. This can confirm the literature conclusions that mostly women are involved in activities for non-governmental organizations. However, in the surveyed group, the assumption that older people are often involved in the work of the third sector was not confirmed.

The subject literature review allows to note that people who engage in the work of the third sector entities are married, they are people with a high level of education and they usually work professionally. The analysis of marital status of persons examined is presented in Table 3.
W pracę organizacji pozarządowych najczęściej zaangażowane były osoby w wieku 30-39 lat (7 osób), 40-49 lat (6 osób) oraz 50-59 lat (8 osób). Grupy wiekowe skrajne - najmłodsze i najstarsze znacznie rzadziej angażowały się w działalność na rzecz trzeciego sektora. Ponadto w działalność organizacji pozarządowych częściej angażowały się kobiety (17 osób tj. prawie $60 \%$ ogółu) niż mężczyźni. Może to potwierdzać wnioski z literatury, że w działalność na rzecz organizacji pozarządowych zaangażowane sa $\mathrm{w}$ większości kobiety. W badanej grupie nie potwierdziło się jednak założenie, że w pracę organizacji trzeciego sektora często zaangażowane są osoby starsze.

Przegląd literatury przedmiotu pozwala zauważyć, że osoby angażujące się $\mathrm{w}$ pracę podmiotów $\mathrm{z}$ trzeciego sektora pozostają w związkach małżeńskich, są osobami posiadającymi wysoki poziom wykształcenia i z reguły wykonują pracę zawodową. Analizę stanu cywilnego osób badanych prezentuje tabela 3.

Table 3. Marital status of persons working in non-governmental organizations

Tabela 3. Stan cywilny osób podejmujących pracę w organizacjach pozarządowych

\begin{tabular}{|l|c|c|c|c|}
\hline & $\begin{array}{c}\text { Woman/ } \\
\text { Kobieta }\end{array}$ & $\begin{array}{c}\text { Man/ } \\
\text { Mężczyzna }\end{array}$ & $\begin{array}{c}\text { Sum/ } \\
\text { Suma }\end{array}$ & $\begin{array}{c}\text { in \%/ } \\
\text { w \% }\end{array}$ \\
\hline $\begin{array}{l}\text { single/ } \\
\text { kawaler/panna }\end{array}$ & 2 & 6 & 8 & 26.6 \\
\hline $\begin{array}{l}\text { divorced/ } \\
\text { rozwiedziony/rozwie- } \\
\text { dziona }\end{array}$ & 2 & 0 & 2 & 6.7 \\
\hline
\end{tabular}




\begin{tabular}{|l|c|c|c|c|}
\hline & $\begin{array}{c}\text { Woman/ } \\
\text { Kobieta }\end{array}$ & $\begin{array}{c}\text { Man/ } \\
\text { Mężczyzna }\end{array}$ & $\begin{array}{c}\text { Sum/ } \\
\text { Suma }\end{array}$ & $\begin{array}{c}\text { in \%/ } \\
\text { w \% }\end{array}$ \\
\hline $\begin{array}{l}\text { widower/widow/ } \\
\text { wdowiec/wdowa }\end{array}$ & 2 & 0 & 2 & 6.7 \\
\hline $\begin{array}{l}\text { married/ } \\
\text { żonaty/zamężna }\end{array}$ & 11 & 7 & 18 & 60 \\
\hline $\begin{array}{l}\text { Total/ } \\
\text { Razem }\end{array}$ & 17 & 13 & 30 & 100 \\
\hline
\end{tabular}

Source: own study based on the carried out research.

Źródło: Opracowanie własne na podstawie przeprowadzonych badań.

The data presented in the table above indicate that participants of research were usually married (18 people, i.e. $60 \%$ of the total).

The level of education and the situation of respondents in the labor market is presented in table 4.
Dane zaprezentowane $\mathrm{w}$ powyższej tabeli wskazują, że uczestnicy badania na ogół pozostawali w związkach małżeńskich (18 osób tj. 60\% ogółu).

Poziom wykształcenia oraz sytuacja respondentów na rynku pracy została przedstawiona w tabeli 4.

Table 4. The level of education of respondents, including employment in the labor market

Tabela 4. Poziom wykształcenia badanych respondentów z uwzględnieniem zatrudnienia na rynku pracy

\begin{tabular}{|c|c|c|c|c|c|}
\hline & $\begin{array}{c}\text { Non-profit sour- } \\
\text { ces of income, e.g. } \\
\text { pensions/ } \\
\text { Niezarobkowe } \\
\text { źródła utrzyma- } \\
\text { nia np. emerytu- } \\
\text { ry, renta } \\
\end{array}$ & $\begin{array}{c}\text { Lack of employ- } \\
\text { ment in the labor } \\
\text { market/ } \\
\text { Brak zatrud- } \\
\text { nienia na rynku } \\
\text { pracy }\end{array}$ & $\begin{array}{l}\text { Employment in } \\
\text { the labor market/ } \\
\text { Zatrudnienie na } \\
\text { rynku pracy }\end{array}$ & $\begin{array}{l}\text { Total/ } \\
\text { Razem }\end{array}$ & $\begin{array}{l}\text { in \%/ } \\
\text { w \% }\end{array}$ \\
\hline $\begin{array}{l}\text { Basic vocational/ } \\
\text { Zasadnicze zawo- } \\
\text { dowe }\end{array}$ & 0 & 0 & 3 & 3 & 10.0 \\
\hline $\begin{array}{l}\text { General secondary/ } \\
\text { Średnie ogólne }\end{array}$ & 1 & 0 & 1 & 2 & 6.7 \\
\hline $\begin{array}{l}\text { Secondary vocatio- } \\
\text { nal education/ } \\
\text { Średnie zawodowe }\end{array}$ & 0 & 0 & 2 & 2 & 6.7 \\
\hline $\begin{array}{l}\text { Higher/ } \\
\text { Wyższe }\end{array}$ & 4 & 1 & 18 & 23 & 76.7 \\
\hline $\begin{array}{l}\text { Total/ } \\
\text { Razem }\end{array}$ & 5 & 1 & 24 & 30 & \multirow{2}{*}{100} \\
\hline $\begin{array}{l}\text { in } \% / \\
\text { w } \%\end{array}$ & 16.7 & 3.3 & 80.0 & 100 & \\
\hline
\end{tabular}

Source: own study based on the carried out research.

Źródło: Opracowanie własne na podstawie przeprowadzonych badań.

The persons involved in the activities of nongovernmental organizations in the Subcarpathian Province had mostly higher education $(76.7 \%$ of the total) and worked professionally (80\% of the total). The collected empirical data confirm the fact that a high level of education, being married and working professionally are conducive to engaging in work for non-governmental organizations.

The persons participating in research were managing non-governmental entities which had two organizational forms, i.e. they were foundations or associations (see tab. 5).

The highest percentage of respondents managed non-governmental organizations that brought together $11-20$ people (20\% of the total) and 2130 people $(20 \%$ of the total). There were relatively few small organizations which brought together up to 6 people $(6.7 \%$ of the total). The number of large
Osoby zaangażowane w działalność organizacji pozarządowych $\mathrm{w}$ województwie podkarpackim w większości posiadały wykształcenie wyższe (76,7\% ogółu) i pracowały zawodowo (80\% ogółu). Zgromadzone dane empiryczne potwierdzają fakt, że wysoki poziom wykształcenia, pozostawanie w związku małżeńskim oraz wykonywanie pracy zawodowej sprzyja angażowaniu się w pracę na rzecz organizacji pozarządowych.

Osoby uczestniczące $\mathrm{w}$ badaniu kierowały podmiotami pozarządowymi, które posiadały dwie formy organizacyjne tzn. były to fundacje bądź stowarzyszenia (zob. tab. 5).

Największa liczba respondentów kierowała organizacjami pozarządowymi, które zrzeszały 11-20 osób (20\% ogółu) i 21-30 osób (20\% ogółu). Stosunkowo niewiele było organizacji małych, skupiających do 6 osób $(6,7 \%$ ogółu). Niewiele było także organiza- 
organizations was also small, only $10 \%$ of the total brought together over 101 people. cji dużych, jedynie 10\% ogółu zrzeszało powyżej 101 osób.

Table 5. The organizational form and number of people associated in non-governmental entities managed by the respondents (in numbers and \%)

Tabela 5. Forma organizacyjna oraz liczba osób zrzeszonych w podmiotach pozarządowych kierowanych przez respondentów (w liczbach i \%)

\begin{tabular}{|c|c|c|c|c|}
\hline & $\begin{array}{l}\text { Foundation/ } \\
\text { Fundacja }\end{array}$ & $\begin{array}{c}\text { Association/ } \\
\text { Stowarzyszenie }\end{array}$ & $\begin{array}{l}\text { Total/ } \\
\text { Razem }\end{array}$ & $\begin{array}{c}\text { in \%/ } \\
\text { w \% }\end{array}$ \\
\hline $\begin{array}{l}\text { up to } 6 \text { people/ } \\
\text { do } 6 \text { osób }\end{array}$ & 1 & 1 & 2 & 6.7 \\
\hline $\begin{array}{l}7-10 \text { people/ } \\
7-10 \text { osób }\end{array}$ & 2 & 0 & 2 & 6.7 \\
\hline $\begin{array}{l}\text { 11-20 people/ } \\
11-20 \text { osób }\end{array}$ & 2 & 4 & 6 & 20.0 \\
\hline $\begin{array}{l}\text { 21-30 people/ } \\
21-30 \text { osób }\end{array}$ & 1 & 5 & 6 & 20.0 \\
\hline $\begin{array}{l}\text { 31-40 people/ } \\
31-40 \text { osób }\end{array}$ & 2 & 2 & 4 & 13.3 \\
\hline $\begin{array}{l}\text { 41-100 people/ } \\
41-100 \text { osób }\end{array}$ & 1 & 2 & 3 & 10.0 \\
\hline $\begin{array}{l}\text { over } 101 \text { people/ } \\
\text { powyżej } 101 \text { osób }\end{array}$ & 1 & 2 & 3 & 10.0 \\
\hline $\begin{array}{l}\text { no answer/ } \\
\text { brak odpowiedzi }\end{array}$ & 3 & 1 & 4 & 13.3 \\
\hline $\begin{array}{l}\text { Total/ } \\
\text { Razem }\end{array}$ & 13 & 17 & 30 & 100 \\
\hline
\end{tabular}

Source: Own study based on the carried out research.

Źródło: Opracowanie własne na podstawie przeprowadzonych badań.

The performed study showed that the goals of functioning of non-government organizations managed by the respondents were very broad, yet they related to the activities in the area of social aid, charity or health care (Table 6).
Przeprowadzone badanie pokazało, iż cele funkcjonowania organizacji pozarządowych, którymi kierowali respondenci były bardzo szerokie, jednakże odnosiły się do działań z zakresu pomocy społecznej, działalności charytatywnej bądź ochrony zdrowia (tab. 6).

Table 6. Directions of the activities of non-governmental organizations managed by respondents

Tabela 6. Kierunki działalności organizacji pozarządowych kierowanych przez respondentów

\begin{tabular}{|c|l|c|c|}
\hline $\begin{array}{c}\text { No./ } \\
\text { Lp. }\end{array}$ & \multicolumn{1}{|c|}{$\begin{array}{c}\text { The direction of the activities of non-governmental } \\
\text { Krganizations/ }\end{array}$} & $\begin{array}{c}\text { Total number of indica- } \\
\text { tions*/ } \\
\text { Łączna liczba wskazań* }\end{array}$ & $\begin{array}{c}\text { in \%/ } \\
\text { w \% }\end{array}$ \\
\hline 1 & $\begin{array}{l}\text { Sport, leisure, tourism, hobby/ } \\
\text { Sport, rekreacja, turystyka, hobby }\end{array}$ & 3 & 5.9 \\
\hline 2 & Art and culture/ Kultura i sztuka & 2 & 3.9 \\
\hline 3 & Education and upbringing/ Edukacja i wychowanie & 26 & 51 \\
\hline 4 & $\begin{array}{l}\text { Social services, social aid, humanitarian aid, rescue services/ } \\
\text { Usługi socjalne, pomoc społeczna, humanitarna, ratownictwo }\end{array}$ & 11 & 21.6 \\
\hline 5 & Health care/ Ochrona zdrowia & 8 & 15.7 \\
\hline 6 & $\begin{array}{l}\text { Local development in the social and economic dimension/ } \\
\text { Rozwój lokalny w wymiarze społecznym i ekonomicznym }\end{array}$ & 1 & 2 \\
\hline 7 & Other/ Pozostałe Total/ Razem & 51 & 100 \\
\hline
\end{tabular}

*the surveyed non-governmental organizations were allowed to indicate a maximum of 3 directions of their activity, hence the number of indications is greater than the number of the surveyed entities/

badane organizacje pozarządowe mogły wskazać maksymalnie 3 kierunki działalności, stąd liczba wskazań jest większa od liczby badanych podmiotów

Source: Own study based on the carried out research.

Źródło: Opracowanie własne na podstawie przeprowadzonych badań. 
The results of the research on this subject should not be surprising, since as it has been mentioned at the beginning of the article, the surveyed organizations had been selected randomly, based on their area of interest, such as social aid, charity and health care.

\section{Non-economic determinants affecting work in non-governmental organizations}

Scientific publications (see e.g. Wang, Graddy, 2008; Śliwiak, 2000) suggested that religious people who have moral authorities associated with charity often engage in activities which support the third sector. Table 7 depicts the analysis of the results due to religion and participation in religious practices.
Wyniki badań w tym zakresie nie powinny być zaskakujące, gdyż jak wspomniano na wstępie artykułu do badań ankietowych wybrano losowo organizacje, które zajmowały się pomocą społeczną, pomocą charytatywną i ochroną zdrowia.

\section{Uwarunkowania pozaekonomiczne podejmowa- nia pracy $w$ organizacjach pozarządowych}

Publikacje naukowe (zob. m.in. Wang, Graddy, 2008; Śliwiak, 2000) sugerowały, że osoby religijne, posiadające autorytety moralne związane $\mathrm{z}$ działalnością charytatywną często angażują się w działalność na rzecz trzeciego sektora. Analiza wyników ze względu na wyznanie religijne oraz uczestnictwo w praktykach religijnych prezentuje tabela 7 .

Table 7. Religion and participation in religious practices among the surveyed respondents involved in the work for nongovernmental organizations

Tabela 7. Wyznanie religijne i uczestnictwo w praktykach religijnych wśród badanych respondentów zaangażowanych w pracę w organizacjach pozarządowych

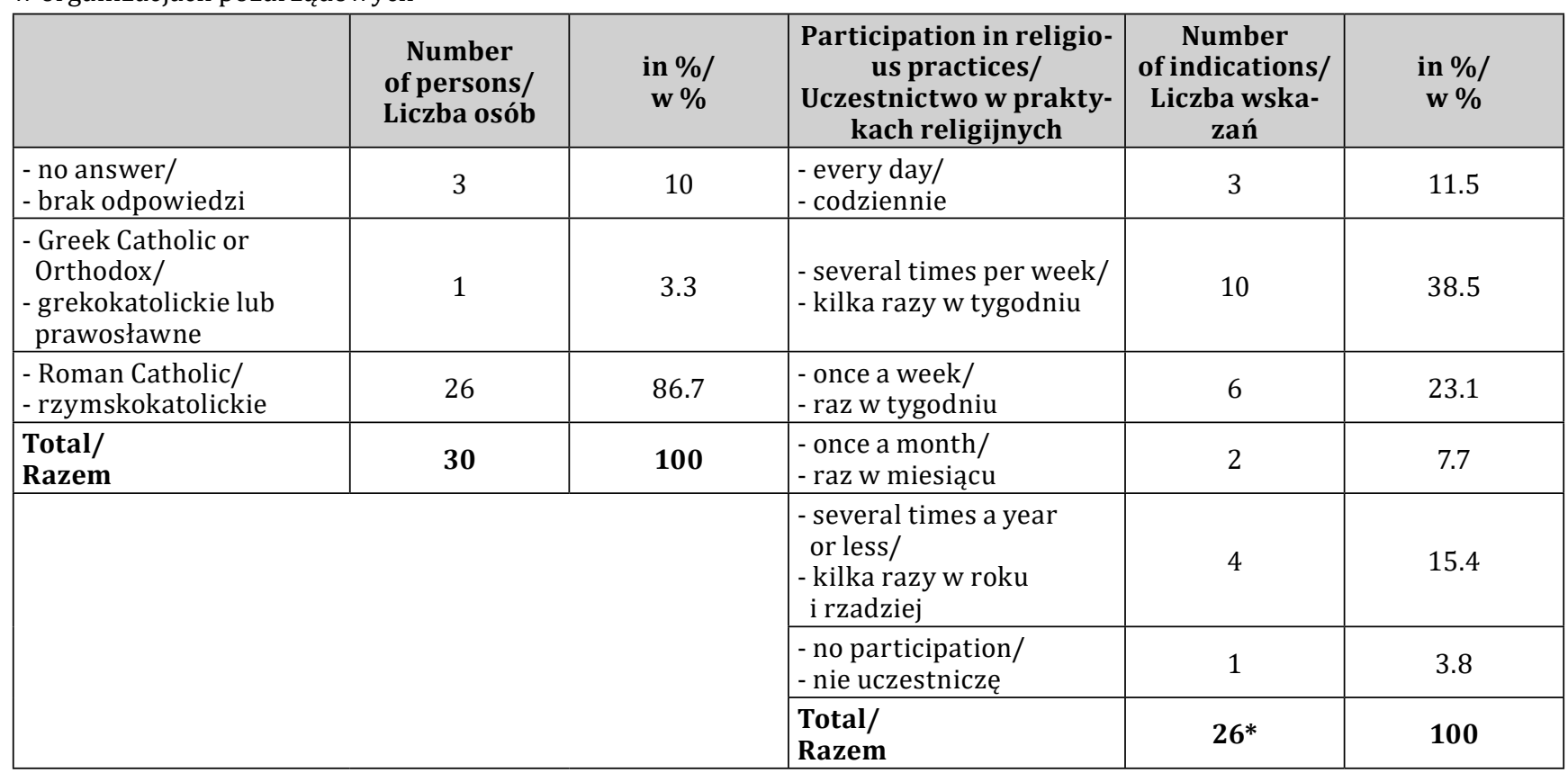

*4 people refused to answer this question/ 4 osoby odmówiły odpowiedzi na to pytanie

Source: Own study based on the carried out research.

Źródło: Opracowanie własne na podstawie przeprowadzonych badań.

People involved in charity activities in the Subcarpathian Province who participated in the study are mostly Roman Catholic (almost 90\% of the total). Moreover, these people often engage in religious practices - almost $75 \%$ of all respondents indicated that they attend religious services at least once a week (e.g. prayer, the Holy Mass).

Almost $67 \%$ of the surveyed persons claimed that they have moral authorities in their lives involved in charity (see Table 8).

As shown in Table 9, the most frequently indicated authorities participating in charity activities were people associated with religion: the Holy Father, John Paul II, Mother Teresa of Calcutta, Edmund Bojanowski.
W województwie podkarpackim osoby zaangażowane w działalność dobroczynną, które uczestniczyły w badaniu były przeważnie wyznania rzymskokatolickiego (prawie 90\% ogółu). Ponadto osoby te często uczestniczą w praktykach religijnych- prawie $75 \%$ ogółu badanych wskazywało, że przynajmniej raz w tygodniu uczestniczy w praktykach religijnych (np. modlitwa, msza św.).

Niemalże $67 \%$ badanych osób działających w organizacjach pozarządowych określiło, że w swoim życiu posiada autorytety moralne związane $\mathrm{z}$ działalnością charytatywną (zob. tab. 8).

Najczęściej wskazywanymi autorytetami w działalności dobroczynnej były postaci związane $\mathrm{z}$ działalnością religijną: Ojciec Sw. Jan Paweł II, Matka Teresa z Kalkuty, Edmund Bojanowski, co prezentuje tabela 9. 
Table 8. Having moral authority involved in charity among the respondents

Tabela 8. Posiadanie autorytetów moralnych związanych z działalnością dobroczynną wśród respondentów

\begin{tabular}{|c|c|c|}
\hline & $\begin{array}{c}\text { Number of persons/ } \\
\text { Liczba osób }\end{array}$ & $\begin{array}{l}\text { in \%/ } \\
\text { w \% }\end{array}$ \\
\hline I do not have any authorities/ Nie posiadam autorytetów & 4 & 13.3 \\
\hline I have authorities/ Posiadam autorytety & 20 & 66.7 \\
\hline I have no opinion/ Nie mam zdania & 6 & 20.0 \\
\hline Total/ Razem & 30 & 100 \\
\hline
\end{tabular}

Source: Own study based on the carried out research.

Źródło: Opracowanie własne na podstawie przeprowadzonych badań.

Table 9. Respondents' moral authorities engaged in charity activities

Tabela 9. Autorytety moralne odnoszące się do działalności dobroczynnej wśród respondentów

\begin{tabular}{|c|c|}
\hline $\begin{array}{l}\text { Respondent's } \\
\text { number/ } \\
\text { Nr respondenta }\end{array}$ & $\begin{array}{l}\text { Who is your moral authority in undertaking charity activities/ } \\
\text { Kto jest Pana/i autorytetem w podejmowaniu działalności dobroczynnej }\end{array}$ \\
\hline 1 & $\begin{array}{l}\text { The Holy Father John Paul II, Mother Teresa of Calcutta/ } \\
\text { Ojciec Św. Jan Paweł II, Matka Teresa z Kalkuty }\end{array}$ \\
\hline 29 & There are several such people/ Jest kilka takich osób \\
\hline 3 & Many/ Wielu \\
\hline 27 & John Paul II, Janusz Korczak/ Jan Paweł II, Janusz Korczak \\
\hline 25 & Caritas/ Caritas \\
\hline 6 & Pope John Paul II/ Papież Jan Paweł II \\
\hline 8 & $\begin{array}{l}\text { Mother Teresa from Calcutta, John Paul II, Anna Dymna/ } \\
\text { Matka Teresa z Kalkuty, Jan Paweł II, Anna Dymna } \\
\end{array}$ \\
\hline 10 & Edmund Bojanowski/ Edmund Bojanowski \\
\hline 11 & Mother Teresa of Calcutta/ Matka Teresa z Kalkuty \\
\hline 12 & Saint John Paul II, Mother Teresa of Calcutta/ Św. Jan Paweł II, Matka Teresa z Kalkuty \\
\hline 14 & Anna Dymna/ Anna Dymna \\
\hline 15 & Princess Diana/ Księżna Diana \\
\hline 20 & $\begin{array}{l}\text { Jesus Christ, Saint Albert Chmielowski, Saint John Paul II/ } \\
\text { Jezus Chrystus, św. Brat Albert, św. Jan Paweł II }\end{array}$ \\
\hline 18 & $\begin{array}{l}\text { Marek Kotański, Janusz Korczak, Jurek Owsiak, Maria Dulębianka/ } \\
\text { Marek Kotański, Janusz Korczak, Jurek Owsiak, Maria Dulębianka }\end{array}$ \\
\hline
\end{tabular}

Source: Own study based on the carried out research.

Źródło: Opracowanie własne na podstawie przeprowadzonych badań.

Anna Dymna, Jurek Owsiak, Marek Kotański and Maria Dulębianka were also considered as authority figures by respondents. The analysis of the research results reveals that the surveyed respondents most often chose people who based their charity activities on the values coming from the Gospel. The results of the survey support the findings from the subject literature. Religiousness, participation in religious practices and having moral authority associated with charity have a significant impact on the involvement in the work for the third sector.

Personal experience of difficult life situations such as: homelessness, poverty, unemployment and addictions, encourage people to undertake work in non-governmental organizations. The available publications show that also living in the environment in which family members and friends undertake charityactivities make people more willing to take up charity activities. Table 10 shows that it is difficult to clearly state whether personal experiences also triggered people's interest in working for nongovernmental organizations.
Jako autorytety wskazywano również Annę Dymną, Jurka Owsiaka, Marka Kotańskiego oraz Marię Dulębiankę. Na podstawie analizy wyników badań można wskazać, iż badani respondenci wskazywali najczęściej osoby, które opierały swoją działalność dobroczynną na wartościach płynących z Ewangelii. Wyniki badania ankietowego potwierdzają wnioski płynące z literatury przedmiotu. Religijność, uczestniczenie $w$ praktykach religijnych i posiadanie autorytetów moralnych związanych z działalnością charytatywną istotnie wpływa na angażowanie się w pracę podmiotów z trzeciego sektora.

Osobiste doświadczanie trudnych sytuacji życiowych związanych m.in. z bezdomnością, ubóstwem, bezrobociem czy uzależnieniami sprzyja podejmowaniu pracy $\mathrm{w}$ organizacjach pozarządowych. Dostępne publikacje wskazują, że podobny wpływ na działalność w podmiotach trzeciego sektora ma również obserwowanie działań dobroczynnych wśród rodziny i przyjaciół. W badanej populacji trudno jest jednoznacznie wskazać czy osobiste doświadczenia były impulsem do zaangażowania się $\mathrm{w}$ pracę organizacji pozarządowych, co przedstawia tabela 10 . 
Table 10. Personal experience of difficult life situations as a reason for the respondents' involvement in working in nongovernmental organizations

Tabela 10. Osobiste doświadczenia trudnej sytuacji życiowej jako przyczyna angażowania się w pracę w organizacjach pozarządowych wśród respondentów

\begin{tabular}{|c|c|c|}
\hline & $\begin{array}{c}\text { Number of persons/ } \\
\text { Liczba osób }\end{array}$ & $\begin{array}{r}\text { in \%/ } \\
\text { w \% }\end{array}$ \\
\hline $\begin{array}{l}\text { Personal experience was not the reason for people's involvement in the } \\
\text { work for the third sector/ } \\
\text { Osobiste doświadczenia nie były przyczyną zaangażowania się w pracę } \\
\text { na rzecz trzeciego sektora }\end{array}$ & 16 & 53 \\
\hline $\begin{array}{l}\text { Personal experience was the reason for people's involvement in the work } \\
\text { for the third sector/ } \\
\text { Osobiste doświadczenia były przyczyną zaangażowania się w pracę na } \\
\text { rzecz trzeciego sektora }\end{array}$ & 14 & 47 \\
\hline Total/ Razem & 30 & 100 \\
\hline
\end{tabular}

Source: Own study based on the carried out research.

Źródło: Opracowanie własne na podstawie przeprowadzonych badań.

The respondents' answers were divided almost evenly: $47 \%$ of respondents indicated that they decided to work for non-governmental organizations due to some difficult life situations. Some of the respondents' opinions were as follows: I also used to be homeless and felt socially excluded and invisible; an unfortunate accident of a family member, a coma. However, $53 \%$ of respondents pointed out that it was not their personal experience that acted as the main trigger for their involvement in the activities for the third sector.

Moreover, it proves problematic to confirm the hypothesis that observing charity behavior among family members encourages people to work in nongovernmental organizations (see figure 1).
Odpowiedzi respondentów były podzielone prawie po połowie, $47 \%$ badanych wskazało, że z powodu doświadczenia trudnej sytuacji życiowej zaangażowało się w pracę na rzecz organizacji pozarządowych. Pojawiły się tutaj następujące wypowiedzi respondentów: sam byłem osobq bezdomna, wykluczonq społecznie, niewidzialna; nieszczęśliwy wypadek członka rodziny, śpiączka. Jednak 53\% respondentów stwierdziło, że to nie osobiste przeżycia były głównym determinantem ich działalności na rzecz trzeciego sektora.

Trudno jest również potwierdzić w badanej populacji hipotezę zakładającą, że obserwowanie zachowań dobroczynnych $w$ rodzinie będzie skłaniało do podejmowania pracy $\mathrm{w}$ organizacjach pozarządowych (zob. rysunek 1).

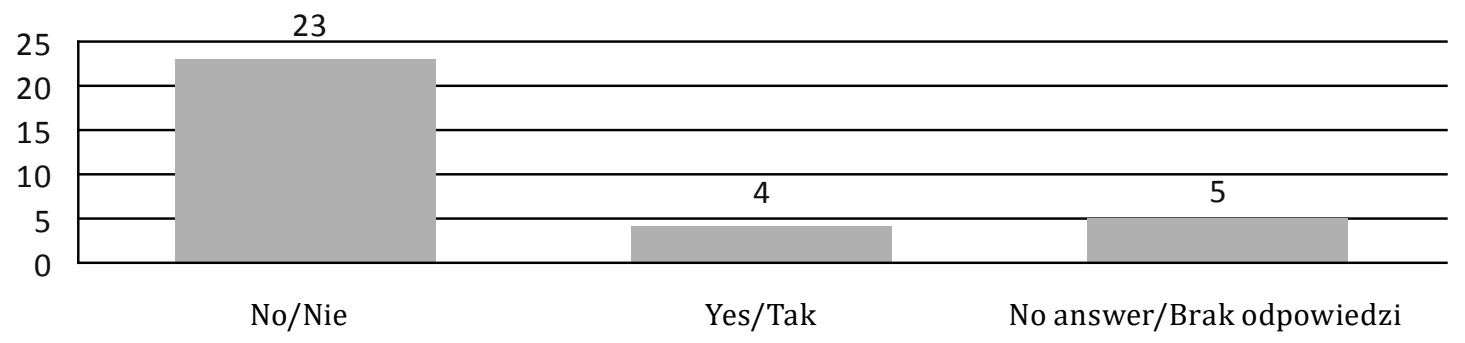

Figure 1. The involvement of the respondents' parents in charity activities

Rysunek 1. Zaangażowanie rodziców badanych osób w działalność dobroczynną

Source: Own study based on the carried out research.

Źródło: Opracowanie własne na podstawie przeprowadzonych badań.

Only 4 respondents indicated that their parents were involved in the activities of the third sector's organization, and the vast majority of respondents (23 people) replied that their parents did not undertake charity work.

Experiencing help, support, mutual understanding in a family home can encourage the involvement in work in non-governmental organizations. The results of analyses of the conducted research are presented in Table 11.
Jedynie 4 respondentów wskazało, że ich rodzice byli zaangażowani $w$ działalność organizacji trzeciego sektora, a zdecydowana większość (23 osoby) udzieliła odpowiedzi, że w ich domu rodzice nie zajmowali się działalnością o charakterze dobroczynnym.

Doświadczanie pomocy, wsparcia, wzajemnego zrozumienia w domu rodzinnym może sprzyjać angażowaniu się $\mathrm{w}$ pracę organizacji pozarządowych. Wyniki analiz przeprowadzonych badań prezentuje tabela 11. 
Table 11. Support at the family home among respondents involved in the activities of non-governmental organizations

Tabela 11. Wsparcie w domu rodzinnym wśród respondentów zaangażowanych w działalność organizacji pozarządowych

\begin{tabular}{|l|c|}
\hline & $\begin{array}{c}\text { in \%* } \\
\text { w \%* }\end{array}$ \\
\hline we could always count on each other/ zawsze mogliśmy na siebie liczyć & 74.1 \\
\hline we only supported each other in difficult times/ wspieraliśmy się tylko w trudnych chwilach & 18.5 \\
\hline we could only count on ourselves/ mogliśmy liczyć tylko na siebie & 7.4 \\
\hline Total/ Razem & $\mathbf{1 0 0}$ \\
\hline
\end{tabular}

* 3 people refused to answer this question/ 3 osoby odmówiły odpowiedzi na to pytanie

Source: own study based on the carried out research.

Źródło: Opracowanie własne na podstawie przeprowadzonych badań.

In the surveyed group, people reported that in the family home they could always count on the support and understanding, only 2 respondents indicated that they could count on the support of family members only in exceptional, difficult times.

A similar distribution of data was obtained in the question about the communication process in the home of the respondents. Almost $67 \%$ of the respondents indicated that they could talk openly about everything in their family homes, and only two people $(7.4 \%$ of the total) surveyed said that these conversations were about irrelevant matters and there were some particular taboo subjects (see tab. 12).
W badanej grupie osoby podawały, iż w domu rodzinnym zawsze mogły liczyć na wsparcie i zrozumienie, jedynie 2 respondentów wskazało, że mogli liczyć na wsparcie członków rodziny tylko w wyjątkowych, trudnych chwilach.

Podobny rozkład danych uzyskano w pytaniu dotyczącym procesu komunikacji w domu rodzinnym badanych. Prawie 67\% ankietowanych wskazało, że mogło rozmawiać w swoich domach rodzinnych otwarcie o wszystkim, a jedynie dwie osoby $(7,4 \%$ ogółu) ankietowanych określiło, że rozmowy te były o rzeczach nieistotnych oraz istniało pewne tabu (zob. tab. 12).

Table 12. Communication in the family home of the respondents involved in the activities of non-governmental organizations Tabela 12. Komunikacja w domu rodzinnym respondentów zaangażowanych w działalność organizacji pozarządowych

\begin{tabular}{|l|c|}
\hline & $\begin{array}{c}\text { in \%* } \\
\text { w \%* }\end{array}$ \\
\hline we could talk about everything openly/ mogliśmy o wszystkim rozmawiać otwarcie & 66.7 \\
\hline we talked only about important matters/ rozmawialiśmy tylko o sprawach istotnych & 22.2 \\
\hline we talked about minor matters, there is a taboo/ rozmawialiśmy o sprawach mało ważnych, istnieje tabu & 7.4 \\
\hline we did not talk to each other/ nie rozmawialiśmy ze sobą & 3.7 \\
\hline Total/ Razem & $\mathbf{1 0 0}$ \\
\hline
\end{tabular}

* 3 people refused to answer this question/ 3 osoby odmówiły odpowiedzi na to pytanie

Source: own study based on the carried out research.

Źródło: Opracowanie własne na podstawie przeprowadzonych badań.

During the research, information was sought about the parents' involvement in solving respondents' problems, as presented in Table 13.
W trakcie badania poszukiwano informacji o zaangażowaniu się rodziców respondentów w rozwiązywanie ich problemów, co prezentuje tabela 13.

Table 13. The involvement of the respondents' parents in solving their problems

Tabela 13. Angażowanie się rodziców respondentów w rozwiązywanie ich problemów

\begin{tabular}{|l|c|}
\hline & $\begin{array}{c}\text { in } \mathbf{\%}^{*} \\
\text { w \%* }\end{array}$ \\
\hline $\begin{array}{l}\text { Yes, they supported me in difficult times, they helped me in solving problems/ tak, wspierali mnie } \\
\text { w trudnych chwilach, pomagali mi rozwiązywać problemy }\end{array}$ & 71.4 \\
\hline Yes, but against my will, imposing their will on me/ tak, ale wbrew mojej woli, narzucając mi swoją wolę & 10.7 \\
\hline no, I was alone with my problems/ nie, byłem sam ze swoimi problemami & 17.9 \\
\hline Total/ Razem & $\mathbf{1 0 0}$ \\
\hline
\end{tabular}

* 2 people refused to answer this question, hence 28 questionnaires were used for the analysis/ *2 osoby odmówiły odpowiedzi na to pytanie, stąd do analizy użyto 28 ankiet

Source: own study based on the carried out research.

Źródło: Opracowanie własne na podstawie przeprowadzonych badań.

A significant part of the surveyed group (71.4\%) stated that they could count on help from their parents
Znaczna część badanej grupy (71,4\%) oświadczyła, że mogła liczyć w trudnych chwilach na pomoc ro- 
during difficult times, and only 5 people indicated that they were forced to solve their problems on their own.

The collected empirical material allowed to observve that experiencing help, support, mutual understanding in a family home can be conducive to engaging in the work of the non-governmental organizations. In this case, however, some caution should be taken when formulating general conclusions. A proper educational process related to the functioning of the family may not only encourage people to work in the non-governmental organizations, but may contribute to shaping the appropriate level of social capital ${ }^{4}$ that makes individuals have a civic attitude.

Scientific literature assigns a number of functions to the non-governmental organizations, among which M. Winiarski (1993, pp. 188-189) also lists the enrichment of social life and the shaping the democratic social relations. The conducted empirical study also allowed to determine whether working in non-governmental organizations allows for enriching the lives of individuals who function in the third sector and what non-material benefits are brought by working in non-governmental organizations. The results of these analyses are presented in Table 14. dziców, a jedynie 5 osób wskazało, że były zmuszone samodzielnie rozwiązywać swoje problemy.

Zebrany materiał empiryczny pozwolił zauważyć, że doświadczanie pomocy, wsparcia, wzajemnego zrozumienia w domu rodzinnym może sprzyjać angażowaniu się $\mathrm{w}$ pracę organizacji pozarządowych. W tym przypadku należy jednak zachować pewną ostrożność przy formułowaniu wniosków ogólnych. Prawidłowy proces wychowawczy związany z funkcjonowaniem rodziny może nie tyle skłaniać do podejmowania pracy w organizacjach pozarządowych, co przyczyniać się do kształtowania odpowiedniego poziomu kapitału społecznego ${ }^{4}$, który sprawia, że jednostki posiadają obywatelskie nastawienie.

Literatura naukowa przypisuje organizacjom pozarządowym szereg funkcji, wśród których M. Winiarski (1993, s. 188-189), wymienia także wzbogacanie życia społeczeństwa i kształtowanie demokratycznych stosunków społecznych. Przeprowadzone badanie empiryczne pozwoliło również ustalić czy praca $\mathrm{w}$ organizacjach pozarzadowych pozwala na wzbogacanie życia jednostek, które funkcjonują $\mathrm{w}$ trzecim sektorze i jakie korzyści niematerialne przynosi praca w organizacjach pozarządowych. Wyniki owych analiz zaprezentowano w tabeli 14.

Table 14. Non-material benefits from working in non-governmental organizations according to the respondents and their effect on the involvement of the immediate environment in the activities for third sector entities

Tabela 14. Korzyści niematerialne $\mathrm{z}$ pracy $\mathrm{w}$ organizacjach pozarządowych $\mathrm{w}$ opinii respondentów oraz ich wpływ w angażowanie się najbliższego otoczenia w działalność na rzecz podmiotów trzeciego sektora

\begin{tabular}{|c|c|c|c|c|c|}
\hline $\begin{array}{l}\text { Non-material benefits from } \\
\text { working in NGOs according to the } \\
\text { respondents/ } \\
\text { Korzyści niematerialne z pracy w } \\
\text { NGO w opinii badanych }\end{array}$ & $\begin{array}{c}\text { number } \\
\text { of indica- } \\
\text { tions*/ } \\
\text { liczba } \\
\text { wskazań* }\end{array}$ & $\begin{array}{l}\text { in \%/ } \\
\text { w \% }\end{array}$ & $\begin{array}{c}\text { The impact of the respondents' } \\
\text { involvement in the work of NGOs } \\
\text { on the immediate environment } \\
\text { (family, friends, acquaintances)/ } \\
\text { Wpływ zaangażowania respon- } \\
\text { dentów w prace NGO na środowi- } \\
\text { sko najbliższe (rodzina, przyjacie- } \\
\text { le, znajomi) }\end{array}$ & $\begin{array}{l}\text { number } \\
\text { of pe- } \\
\text { ople/ } \\
\text { liczba } \\
\text { osób }\end{array}$ & $\begin{array}{c}\text { in \%/ } \\
\text { w \% }\end{array}$ \\
\hline $\begin{array}{l}\text { a changed view of life/ } \\
\text { zmienione spojrzenie na życie }\end{array}$ & 19 & 19.4 & \multirow{4}{*}{$\begin{array}{l}\text { My involvement into work in the } \\
\text { NGOs made the people from my } \\
\text { immediate environment also get } \\
\text { involved in charity activities/ } \\
\text { Moje zaangażowanie w pracę w org. } \\
\text { pozarządowych sprawiło, że osoby } \\
\text { z najbliższego środowiska również } \\
\text { zaangażowały się w działalność o } \\
\text { charakterze dobroczynnym }\end{array}$} & \multirow{4}{*}{23} & \multirow{4}{*}{76.7} \\
\hline $\begin{array}{l}\text { a sense of a well-fulfilled duty/ } \\
\text { poczucie dobrze spełnionego obo- } \\
\text { wiązku }\end{array}$ & 22 & 22.4 & & & \\
\hline $\begin{array}{l}\text { new professional contacts/ } \\
\text { nowe kontakty zawodowe }\end{array}$ & 9 & 9.2 & & & \\
\hline $\begin{array}{l}\text { acquiring new useful skills/ } \\
\text { nabycie nowych przydatnych umie- } \\
\text { jętności }\end{array}$ & 21 & 21.4 & & & \\
\hline
\end{tabular}

\footnotetext{
${ }^{4}$ Social capital is a cultural phenomenon. It is a resource of the community, not the individuals who are a part of it. This phenomenon includes civic attitudes of members of the society, social standards supporting cooperation and interpersonal trust, as well as citizens' trust in public institutions. Trust is the basic element of social capital, which guarantees the best solution to the prisoner's dilemma for the entire community (though not necessarily the most beneficial for each of its members): maximising the common good instead of - as in the case of human capital - maximising the individual utility function (Czapiński, 2008, p. 8).
}

\footnotetext{
${ }^{4}$ Kapitał społeczny jest zjawiskiem kulturowym, stanowi zasób wspólnoty, a nie tworzacych ja jednostek. Obejmuje obywatelskie nastawienie członków społeczeństwa, normy wspierające współdziałanie oraz zaufanie interpersonalne i zaufanie obywateli do instytucji publicznych. Zasadniczym elementem kapitału społecznego jest zaufanie, gwarantujące najlepsze dla całej wspólnoty, choć niekoniecznie najbardziej korzystne dla każdego z jej członków rozwiązanie dylematu więźnia: maksymalizację dobra wspólnego zamiast - jak w przypadku kapitału ludzkiego maksymalizowania indywidualnej funkcji użyteczności (Czapiński, 2008, s. 8).
} 


\begin{tabular}{|c|c|c|c|c|c|}
\hline $\begin{array}{l}\text { Non-material benefits from } \\
\text { working in NGOs according to the } \\
\text { respondents/ } \\
\text { Korzyści niematerialne z pracy w } \\
\text { NGO w opinii badanych }\end{array}$ & $\begin{array}{l}\text { numberof } \\
\text { indica- } \\
\text { tions*/ } \\
\text { liczba } \\
\text { wskazań* }\end{array}$ & $\begin{array}{l}\text { in \%/ } \\
\text { w \% }\end{array}$ & $\begin{array}{c}\text { The impact of the respondents' } \\
\text { involvement in the work of NGOs } \\
\text { on the immediate environment } \\
\text { (family, friends, acquaintances)/ } \\
\text { Wpływ zaangażowania respon- } \\
\text { dentów w pracę NGO na środowi- } \\
\text { sko najbliższe (rodzina, przyjacie- } \\
\text { le, znajomi) }\end{array}$ & $\begin{array}{l}\text { number } \\
\text { of pe- } \\
\text { ople/ } \\
\text { liczba } \\
\text { osób }\end{array}$ & $\begin{array}{l}\text { in \%/ } \\
\text { w \% }\end{array}$ \\
\hline $\begin{array}{l}\text { filling of the free time/ } \\
\text { wypełnienie wolnego czasu }\end{array}$ & 7 & 7.1 & \multirow{2}{*}{$\begin{array}{l}\text { My involvement into work in the } \\
\text { NGOs did not make people from } \\
\text { my immediate environment also } \\
\text { get involved in charity activities/ } \\
\text { Moje zaangażowanie w pracę w org. } \\
\text { pozarządowych nie sprawiło, że oso- } \\
\text { by z najbliższego środowiska rów- } \\
\text { nież zaangażowały się w działalność } \\
\text { o charakterze dobroczynnym }\end{array}$} & \multirow[b]{2}{*}{2} & \multirow[b]{2}{*}{6.7} \\
\hline $\begin{array}{l}\text { meeting new people/ } \\
\text { poznanie nowych osób }\end{array}$ & 19 & 19.4 & & & \\
\hline $\begin{array}{l}\text { other (motivation to overcome life dif- } \\
\text { ficulties by observing people who have } \\
\text { to deal with more serious problems } \\
\text { every day-R26)/ } \\
\text { inne (motywacja do pokonywania } \\
\text { trudności życiowych dzięki obser- } \\
\text { wacji ludzi, którzy muszą na co dzień } \\
\text { zmagać się ze znacznie poważniej- } \\
\text { szymi problemami-R26) }\end{array}$ & 1 & 1.0 & I do not have such knowledge & 5 & 16.7 \\
\hline Total/ Razem & 98 & 100 & Total/Razem & 30 & 100 \\
\hline
\end{tabular}

* surveyed non-governmental organizations could indicate several responses, hence the number of indications is greater than the number of entities surveyed/ badane organizacje pozarządowe mogły wskazać kilka odpowiedzi, stąd liczba wskazań jest większa od liczby badanych podmiotów

Source: own study based on the carried out research.

Źródło: Opracowanie własne na podstawie przeprowadzonych badań.

In the Subcarpathian Province, respondents most often indicated such intangible benefits of their charitye activity as a sense of a well-fulfilled duty (22.4\% of total answers), acquisition of new useful skills $(21.4 \%)$ and a changed view of life and meeting new people (19.4\% of total indications).

A significant part of the respondents (76.7\% of the total) indicated that their aid activities meant that people from the environment were also involved in charity activities. Therefore, it should be assumed that empirical research proved that work in nongovernmental organizations enriches the social and personal life and contributes to shaping democratic social relations.

\section{Conclusions}

The aim of the study was an attempt to present the influence of non-economic factors on undertaking work in non-governmental organizations in one region of Poland, i.e. in the Subcarpathian Province. The research carried out has only confirmed the results of the empirical work partly so far. Scientific literature indicated that a higher level of education, being married and performing professional work encourages the involvement in work in nongovernmental organizations. These conclusions were confirmed in the Subcarpathian Province, where the surveyed people working for the third sector had higher education, were married and worked
W województwie podkarpackim respondenci najczęściej wskazywali na takie korzyści niematerialne swojej działalności dobroczynnej jak poczucie dobrze spełnionego obowiązku $(22,4 \%$ ogółu odpowiedzi), nabycie nowych przydatnych umiejętności $(21,4 \%)$ oraz zmienione spojrzenie na życie i poznanie nowych osób (po 19,4\% ogółu wskazań).

Znacząca cześć respondentów (76,7\% ogółu) wskazywała, że ich działalność pomocowa sprawiła, że osoby ze środowiska również angażowały się w działalność o charakterze chary tatywnym. Należy zatem przyjaḉ, iż badanie empiryczne dowiodło, że praca w organizacjach pozarządowych wzbogaca życie społeczne i osobiste oraz przyczynia się do kształtowania demokratycznych stosunków społecznych.

\section{Zakończenie}

Celem przeprowadzonego badania było podjęcie próby przedstawienia wpływu czynników pozaekonomicznych na podejmowanie pracy $\mathrm{w}$ organizacjach pozarządowych w jednym regionie Polski tj. w województwie podkarpackim. Przeprowadzone badania potwierdziły tylko w części wyniki dotychczasowych prac empirycznych. Literatura naukowa wskazywały, że wyższy poziom wykształcenia, pozostawanie w związkach małżeńskich oraz wykonywanie pracy zawodowej sprzyja angażowaniu się $\mathrm{w}$ prace $\mathrm{w}$ organizacjach pozarządowych. Wnioski te udało się potwierdzić w województwie podkarpackim, gdzie badane osoby pracujące na rzecz trzeciego 
professionally. Therefore, it can be assumed that undertaking employment in non-governmental organizations depends on education, marital status and professional activity on the labor market.

The subject literature indicated that women and older people are more often involved in the work of non-governmental organizations than men and young people. This assumption was only partly confirmed. Mostly women were involved in the activities of non-governmental organizations. However, it has not been possible to confirm that older people are commonly involved in working for the third sector. In the Subcarpathian Province, gender proved to be a conducive factor for engaging in the work of nongovernmental organisations, while age turned out to be an insignificant determinant.

Scientific publications suggested that religious people, who have moral authorities associated with charitable activities, would be more often involved in the activities of the third sector. The conducted survey confirmed that in the Subcarpathian Province religiousness, participation in religious practices and having moral authorities associated with charitable activities had a significant impact on involvement in the work of entities from the third sector.

However, it has not been possible to confirm that either experiencing difficult life situations (such as homelessness, poverty, unemployment, or addictions) or observing charitable activities among family and friends is conducive to involvement in the work of non-governmental organisations.

During the empirical research, the assumption was made that experiencing help, support and mutual understanding in the family home may be conducive to getting involved in the work of non-governmental organisations. Most of the respondents answered that they could always count on support and understanding in their family homes. They could talk about everything, and their parents were involved in solving their problems. However, some caution should be exercised when formulating general conclusions. A proper educational process related to the functioning of the family may not as much encourage involvement in the work of non-governmental organisations, as it may contribute to shaping the social capital, which causes the individuals to have a civic attitude. Undoubtedly, the final confirmation of the influence of this factor would require further in-depth research and analysis.

Surveys have confirmed the assumption that work in non-governmental organisations brings satisfaction, enriches social and personal life, and contributes to shaping democratic social relations.

The conducted research shows that there are factors not connected to economy that encourage involvement in the work of non-governmental organisations in the Subcarpathian Province. Those factors include education, marital status, labour market activity, gender, religion, and moral authority associated with charitable activities. Moreover, undertaking work in the third sector organisations may also be influenced by experiencing help, support and mutual understanding in a family home. The sektora posiadały wyższe wykształcenie, pozostawały w związkach małżeńskich i pracowały zawodowo. Można zatem przyjąć, że podejmowanie pracy $\mathrm{w}$ organizacjach pozarządowych jest uzależnione od wykształcenia, stanu cywilnego i aktywności zawodowej na rynku pracy.

Literatura przedmiotu wskazywała, że kobiety i osoby starsze częściej angażują się w pracę organizacji pozarządowych niż mężczyźni i osoby młode. To założenie udało się potwierdzić jedynie w części. W działalność organizacji pozarządowych zaangażowane były $\mathrm{w}$ większości kobiety. Nie udało się natomiast potwierdzić, że $\mathrm{w}$ pracę na rzecz trzeciego sektora często zaangażowane są osoby starsze. W województwie podkarpackim czynnikiem sprzyjającym angażowaniu się $\mathrm{w}$ pracę organizacji pozarządowych okazała się płeć, zaś wiek okazał się mało istotnym determinantem.

Publikacje naukowe sugerowały, że osoby religijne, posiadające autorytety moralne związane z działalnością charytatywną będą częściej angażowały się w działalność trzeciego sektora. Przeprowadzone badanie ankietowe zdołało potwierdzić, że w województwie podkarpackim religijność, uczestniczenie w praktykach religijnych i posiadanie autorytetów moralnych związanych z działalnością charytatywną istotnie wpływało na angażowanie się $\mathrm{w}$ pracę podmiotów z trzeciego sektora.

Nie udało się natomiast potwierdzić, że doświadczanie trudnych sytuacji życiowych związanych m.in. $\mathrm{z}$ bezdomnością, ubóstwem, bezrobociem czy uzależnieniami bądź też obserwowanie działań dobroczynnych wśród rodziny i przyjaciół sprzyja angażowaniu się $\mathrm{w}$ pracę organizacji pozarządowych.

W trakcie badania empirycznego potwierdzone zostało założenie, że doświadczanie pomocy, wsparcia i wzajemnego zrozumienia $\mathrm{w}$ domu rodzinnym może sprzyjać angażowaniu się $\mathrm{w}$ pracę $\mathrm{w}$ organizacjach pozarządowych. Większość respondentów wskazywała, że w domu rodzinnym zawsze mogli liczyć na wsparcie i zrozumienie, rozmawiać o wszystkim, a rodzice angażowali się $w$ rozwiązywanie ich problemów. Przy formułowaniu wniosków ogólnych w przypadku tego czynnika należy jednak zachować pewną ostrożność. Prawidłowy proces wychowawczy związany z funkcjonowaniem rodziny może nie tyle skłaniać do angażowanie się w pracę organizacji pozarządowych, co przyczyniać się do kształtowania kapitału społecznego, który sprawia, że jednostki posiadają obywatelskie nastawienie. Niewątpliwie ostateczne potwierdzenie zależności w przypadku tego czynnika wymagałoby prowadzenia dalszych pogłębionych badań i analiz.

Badania ankietowe potwierdziły założenie, że praca $\mathrm{w}$ organizacjach pozarządowych przynosi satysfakcję, wzbogaca życie społeczne i osobiste oraz przyczynia się do kształtowania demokratycznych stosunków społecznych.

Na podstawie przeprowadzonego badania można wysunąć wniosek, iż w województwie podkarpackim do pozaekonomicznych czynników skłaniających do angażowania się $w$ pracę organizacji pozarządowych można zaliczyć: wykształcenie, stan cywilny, ak- 
factors such as age, personal experience of difficult life situations, or observing charity activities among family and friends have an insignificant influence on the involvement in the work of non-governmental entities.

The activities of state institutions of social policy focused on increasing the involvement of citizens in the third sector entities, should offer people the possibility of obtaining the highest level of education, stable employment in the labour market, as well as creating conditions for families to function properly. This will contribute to the citizens' involvement in the work of non-governmental organisations. Moreover, public institutions and non-governmental organisations should conduct social campaigns to show citizens that work in non-governmental organisations contributes to enriching social and personal life and to building a civil society.

Finally, it should be noted that some caution should be exercised when formulating general conclusions referring to the entire Subcarpathian Province. The conducted empirical study was not comprehensive, and the research sample was not too diverse. Nevertheless, the results of the empirical study may serve as a contribution to a further indepth discussion on non-economic factors that influence undertaking work in non-governmental organisations in the Subcarpathian Province and in Poland. tywność na rynku pracy, płeć, religijność i posiadanie autorytetów moralnych związanych z działalnością dobroczynną. Ponadto na podejmowanie pracy $\mathrm{w}$ organizacjach $\mathrm{z}$ trzeciego sektora może wpływać również doświadczanie pomocy, wsparcie i wzajemnego zrozumienia $w$ domu rodzinnym. Mało istotny wpływ na angażowanie się w pracę podmiotów pozarządowych miały takie czynniki jak wiek, osobiste doświadczanie trudnych sytuacji życiowych czy też obserwowanie działań dobroczynnych wśród rodziny i przyjaciół.

Działania państwowych instytucji polityki społecznej ukierunkowane na zwiększenie zaangażowania obywateli $\mathrm{w}$ działalność podmiotów z trzeciego sektora powinny więc zmierzać do stworzenia możliwości uzyskiwania jak najwyższego poziomu wykształcenia, stabilnego zatrudnienia na rynku pracy, a także stworzenia możliwości prawidłowego funkcjonowania rodziny. Będzie to przyczyniało się do angażowania się obywateli $\mathrm{w}$ pracę $\mathrm{w}$ organizacjach pozarządowych. Ponadto instytucje publiczne oraz organizacje pozarządowe powinny prowadzić kampanie społeczne tak, aby wskazać obywatelom, że praca w organizacjach pozarządowych przyczynia się do wzbogacenia życia społecznego i osobistego oraz do budowania społeczeństwa obywatelskiego.

Na koniec należy jednak zauważyć, że przy formułowaniu wniosków ogólnych odnoszących się do całego województwa podkarpackiego należy zachować pewną ostrożność. Przeprowadzone badanie empiryczne nie miało bowiem charakteru kompleksowego, a próba badawcza nie była zbyt liczna. Niemniej jednak wyniki badania empirycznego moga być przyczynkiem do dalszej pogłębionej dyskusji o czynnikach pozaekonomicznych wpływających na podejmowanie pracy $w$ organizacjach pozarządowych w województwie podkarpackim i w Polsce.

\section{References/ Literatura:}

1. Bar-Tal, D. (1976). Prosocial behawior. New York: Wiley.

2. Bochyńska-Śmigielska, E. (2012). Determinanty zaangażowania i efektywności zawodowej. Zeszyty Naukowe Towarzystwa Doktorantów UJ Nauki Społeczne, 4(1), 97-113.

3. Braun, K. (2012). Rodzinne uwarunkowania zaangażowania młodzieży w wolontariat. Roczniki Nauk o Rodzinie i Pracy Socjalnej, 4(59), 109-127.

4. Czapiński, J. (2008). Kapitał ludzki i kapitał społeczny a dobrobyt materialny. Polski paradoks. Zarzq̨dzanie Publiczne, 2(4), 5-28.

5. DellaVigna, S., List, J. A., and Malmendier, U. (2012). Testing for altruism and social pressure in charitable giving. The Quarterly Journal Of Economics, 127(1), 1-56. https://doi.org/10.1093/qje/qjr050

6. Govekar, P. L., Govekar, M. A. (2002). Using economic theory and research to better understand volunteer behawior. Nonprofit Management and Leadership, 13(1), 33-48. https://doi.org/10.1002/nml.13104

7. Górecki, M. (2013). Wolontariat - idea, organizacja, doświadczenia. Warmińsko-Mazurski Kwartalnik Naukowy, Nauki Spoteczne, 1, 81-109.

8. Grewiński, M., Kamiński, S. (2007). Obywatelska polityka społeczna. Warszawa: Wydawnictwo Wyższej Szkoły Pedagogicznej TWP.

9. Grotkowski, M. (2011). Trzeci sektor w Polsce - rola i zagrożenia płynące z wypełniania funkcji i zadań administracji publicznej. Forum Studiów i Analiz Politycznych im. Maurycego Mochnackiego.

10. GUS (2012). Wolontariat w organizacjach i inne formy pracy niezarobkowej poza gospodarstwem domowym - 2011; Warszawa: Studia i Analizy Statystyczne.

11. GUS (2014). Wstępne wyniki badania społecznej i ekonomicznej kondycji organizacji trzeciego sektora w 2012 r., Warszawa.

12. GUS- Bank Danych Lokalnych (2017). Pobrane z: http://stat.gov.pl/bdl/app/strona.html?p_name=indeks

13. Jarymowicz, M. (1979). Modyfikowanie wyobrażeń dotyczących „ja” dla zwiększenia gotowości do zachowań prospołecznych. Wrocław: Ossolineum.

14. Kanios, A. (2008). Społeczne kompetencje studentów do pracy w wolontariacie. Lublin: Wydawnictwo UMCS.

15. Karyłowski, J. (1982). O dwóch typach altruizmu. Wrocław: Ossolineum. 
16. Kenrick, D. T., Neuberg, S. L., Cialdini, R. B. (2002). Psychologia społeczna. Gdańsk: Gdańskie Wydawnictwo Psychologiczne. 17. Kietlińska, K. (2010). Rola trzeciego sektora w społeczeństwie obywatelskim. Warszawa: Difin.

18. Kitchen, H., Dalton, R. (1990). Determinants of charitable donations by families in Canada: a regional analysis. Applied Economics, 22(3), 285-299. https://doi.org/10.1080/00036849000000081

19. Klon/Jawor (2012). Życie codzienne organizacji pozarzadowych w Polsce. Warszawa.

20. Lee, Y. K., Chang, C. T. (2007). Who gives what to charity? Characteristics affecting donation behawior. Social Behavior and Personality, 35(9), 1173-1180. https://doi.org/10.2224/sbp.2007.35.9.1173

21. Meier, S., Stutzer, A. (2008). Is volunteering rewarding in itself? Economica, 75(297), 39-59.

22. Odendahl, T. (1990). Charity begins at home: Generosity and self-interest among the philanthropic elite; (Vol. 251). New York: Basic Books.

23. Portal Organizacji Pozarządowych - bazy.ngo.pl

24. Reykowski, J. (1979). Motywacja, postawy prospołeczne a osobowość. Warszawa: PWN.

25. Svítková, K. (2006). Corporate Philanthropy in the Czech and Slovak Republics. Prague: Charles University.

26. Śliwak, J. (2000). Społeczne i sy tuacyjne uwarunkowania zachowań altruistycznych. Przegląd badań. Roczniki Psychologiczne, 03, 35-47.

27. Śliwak, J. (2005). Altruizm i jego pomiar. Kwestionariusz A - N. Roczniki Psychologiczne, VIII(1), 121-144.

28. Taniguchi, H. (2012). The determinants of formal and informal volunteering: Evidence from the American Time Use Survey. Voluntas: International Journal of Voluntary and Nonprofit Organizations, 23(4), 920-939.

29. Tarczydło, B. (2013). Kampania społeczna w teorii i praktyce. W: J. Gołuchowski, A. Frączkiewicz-Wronka (red.), Wykorzystanie nowych mediów w PR (s. 225-234). Katowice: Wydawnictwo Uniwersytetu Ekonomicznego.

30. Tyrakowski, M. (2007). Rola organizacji pozarządowych w rozwiązywaniu problemów społecznych. ZNZE WSIiZ 2(4), 172196.

31. US (2013), Podstawowe dane o wybranych organizacjach trzeciego sektora w 2010, Kraków.

32. US (2015), Podstawowe dane o wybranych organizacjach trzeciego sektora w 2012 r; Kraków.

33. Ustawa z dnia 24 kwietnia 2003 r. o działalności pożytku publicznego i o wolontariacie (Dz. U. z 2018 poz. 450 t.j. z późn zm.)

34. Van Willigen, M. (2000). Differential benefits of volunteering across the life course. The Journals of Gerontology: Psychological Sciences and Social Sciences, 55(5), 308-318. https://doi.org/10.1093/geronb/55.5.S308

35. Wang, L., Graddy, E. (2008). Social capital, volunteering, and charitable giving. Voluntas: International Journal of Voluntary and Nonprofit Organizations, 19(1), 23-42. https://doi.org/10.1007/s11266-008-9055-y

36. Winiarski, M. (1995). Funkcje organizacji i stowarzyszeń społecznych w środowisku lokalnym. W: T. Pilch, I. Lepalczyk (red.), Pedagogika społeczna. Człowiek w zmieniającym się świecie. Warszawa.

37. Yi, D. T. (2010). Determinants of fundraising efficiency of nonprofit organizations: evidence from US public charitable organizations. Managerial and Decision Economics, 31(7), 465-475. https://doi.org/10.1002/mde.1503

38. Zielińska, A. (2011). Rola organizacji pozarządowych w rozwoju społeczno-ekonomicznym Polski. Zeszyty Naukowe Politechniki Rzeszowskiej- Zarzq̨dzanie i Marketing, 18(2), 280-234. 